Check for updates

Cite this: RSC Adv., 2018, 8, 12503

Received 6th January 2018

Accepted 27th March 2018

DOI: $10.1039 / \mathrm{c} 8 \mathrm{ra00145f}$

rsc.li/rsc-advances

\section{Study on the formation and properties of red blood cell-like $\mathrm{Fe}_{3} \mathrm{O}_{4} / \mathrm{TbLa}_{3}(\mathrm{Bim})_{12} /$ PLGA composite particles}

\author{
Ping Li, (D) $\dagger^{\mathrm{ab}}$ Bing Qi,,$^{\mathrm{ab}}$ Kun Li, ${ }^{\mathrm{ab}}$ Junwei Xu, (D) ${ }^{\mathrm{ab}}$ Meili Liu, ${ }^{\mathrm{ab}}$ Xuenan Gu, ${ }^{\mathrm{ab}}$ \\ Xufeng Niu (D) ab and Yubo Fan*abc
}

\begin{abstract}
Besides the particle size and surface performance, the shape also plays a key role in drug delivery systems. Red blood cells are the most abundant blood cells in the human body, and are excellent oxygen carriers, due to their unique biconcave discoid shape. In this study, red blood cell (RBC)-like $\mathrm{Fe}_{3} \mathrm{O}_{4} / \mathrm{TbLa}_{3}(\mathrm{Bim}){ }_{12} /$ poly(lactic-co-glycolic acid) (PLGA) composite particles, with magnetic response and bioimaging functions, were prepared by electrospraying. Various electrospraying parameters, such as solvent, PLGA concentration, collecting distance and solution flow rate were investigated in detail to attempt to obtain RBC-like composite particles. The size distribution, morphology, structure, and hydrophobicityhydrophilicity of particles were characterized. The results revealed the RBC-like $\mathrm{Fe}_{3} \mathrm{O}_{4} / \mathrm{TbLa}_{3}(\mathrm{Bim})_{12} /$ PLGA composite particles exhibited a strong green fluorescence and good magnetic behavior even when incubated with cells. Furthermore, the intensity of the magnetization and fluorescence can be adjusted by changing the contents of $\mathrm{Fe}_{3} \mathrm{O}_{4}$ and $\mathrm{TbLa}_{3}(\mathrm{Bim})_{12}$. The effect on cell viability of the RBC-like $\mathrm{Fe}_{3} \mathrm{O}_{4} / \mathrm{TbLa}_{3}(\mathrm{Bim})_{12} / \mathrm{PLGA}$ composite particles was evaluated in A549 cells and RBCs, and it was determined to have low cytotoxicity and excellent blood biocompatibility, suggesting that it is a promising candidate for application in drug delivery, targeting and tracking.
\end{abstract}

\section{Introduction}

In the biomaterials field, polymeric particles offer the potential to improve biomedical applications, such as targeted drug delivery, vaccination and bioimaging, ${ }^{1-3}$ and have already produced a series of significant results. ${ }^{4-7}$ Most polymeric particles are spherical carriers because of simplicity and versatility of the fabrication process. However, some studies have found that the shape of particles played important roles in evading phagocytosis, margination and targeting. ${ }^{8-10}$ Geng et al. $^{\mathbf{1 1}}$ reported a kind of copolymer micelle assembly, consisting of polyethyleneglycol, polyethylethylene and polycaprolactone, which exhibited about ten times longer circulation time in rodents than the spherical counterpart with similar chemistry. Additionally, they proved that the assembly with paclitaxel could be effectively used to treat the tumor in mice. Godin et $a .^{12}$ found that in breast tumor, discoidal

${ }^{a}$ School of Biological Science and Medical Engineering, Key Laboratory for Biomechanics and Mechanobiology, Ministry of Education, Beihang University, Beijing, 100083, China. E-mail: yubofan@buaa.edu.cn

${ }^{b}$ Beijing Advanced Innovation Centre for Biomedical Engineering, Beihang University, Beijing, 100083, China

${ }^{c}$ Beijing Key Laboratory of Rehabilitation Technical Aids for Old-Age Disability, National Research Center for Rehabilitation Technical Aids, Beijing, 100176, China

$\dagger$ P. Li and B. Qi contributed equally to this work. particles would more likely stick to the vessel walls, and the accumulation of discoidal porous silicons was five times higher compared to the spherical ones with the same diameter. In addition, some theoretical model studies also showed that nonspherical carriers were useful in cellular internalization and vascular dynamics. Decuzzi ${ }^{\mathbf{1 3}}$ calculated the interaction between cylindrical particles and the cell membrane and found that only particles with intermediate aspect ratio could be fully wrapped and eventually internalized. In another study, Decuzzi ${ }^{14}$ analyzed the specific adhesive interaction between a nonspherical particle and a cell layer under a linear shear flow and the result showed that oblate particles adhered more effectively to biological substrate than spherical ones.

Red blood cells (RBCs) with unique biconcave discoid morphology represent a remarkable example of shape enabling the implementation of sophisticated biological functionalities. ${ }^{15}$ For example, RBCs can flow through small bore capillary. ${ }^{16}$ Moreover, the distinctive biconcave discoid shape gives RBCs the ability to protect themselves from being filtered by the spleen. ${ }^{17}$ Accordingly, developing a kind of RBC mimicking carrier with biconcave discoid can be expected to greatly enhance the flow and accumulation of drug in body.

In current studies, the main methods to prepare RBC-like particles are the layer by layer (LBL) method, particle replication in non-wetting templates (PRINT) method, stretching/ compressing method, and electrospraying. Kozlovskaya V. 
et $a .^{18}$ fabricated polymethyl methacrylate (PMMA) discoidal hydrogel capsules to study the internalization of RBCs using the LBL approach, and Merkel T. J. et al. ${ }^{19}$ prepared RBC hydrogel micro-particles by the PRINT method to mimic the mechanobiological properties. However, a template prepared via traditional photolithography was necessary for the two methods mentioned above. Also, Fan J. B. et al. ${ }^{20}$ synthesized anisotropic biodegradable poly(lactic-co-glycolic acid) (PLGA) nanoparticles using the stretching/compressing technique to study the controllable drug release. However, this method required the fabrication of spherical particles at first, then the compressing force was applied to obtain the desire shape like RBC particles.

Electrospraying is a well-established technique for generating mono-dispersed size droplets under an electrical force. It is a one-step, inexpensive and versatile method for preparing particles, which allows to obtain particles with various shapes by adjusting a series of experimental parameters. ${ }^{21-24}$ Hayashi, K. et $a .^{25}$ successfully prepared RBC particles, with magnetic resonance and fluorescence imaging functions, using cellulose derivatives by electrospraying. They pointed out that the sheet structure of the cellulose derivatives contributed to the formation of the RBC morphology, while the polymers without a sheet structure like dextran, polyethylene glycol, and PMMA could not produce a RBC shape. Park, C. H. et al. ${ }^{26}$ synthesized monodisperse RBC-like polyurethane (PAN) particles by electrospraying and he attributed the morphology to the asymmetry diffusivities. When the diffusivity of PAN solutions diffusing into the air/droplet interface was lower than that of solvents diffusing into the surrounding air, the RBC-like particles could be produced. Ju, X. et $a .^{27}$ prepared RBC-shaped chitosan micro-particles using wet-electrospray. In their study, a glass chamber filled with oil and a magnetic stirrer were required as a coagulating bath. They suggested that the key to produce RBC structure was the interaction between the evaporable solvent of the precursor solution and the diffusible solvent in the coagulating bath.

There is an increasing number of multifunctional materials that have been explored, such as magnetic-fluorescent bifunctional materials, ${ }^{28}$ electrical-magnetic bifunctional materials, ${ }^{29}$ fluorescent-electrical bifunctional materials ${ }^{\mathbf{3 0}}$ and electricalmagnetic-fluorescent trifunctional materials. ${ }^{31}$ However, the RBC-like multifunctional PLGA composite particles have not been thoroughly studied, especially via the electrospraying technique. Rare earth (RE) elements exhibit low toxicity, high luminescence quantum yield, narrow bandwidth, large Stokes shifts and ligand-dependent luminescence sensitization. These properties allow RE elements to avoid the intrinsic limitations of traditional dyes, such as short fluorescent lifetime, relatively high bio-toxicity and low chemical stability. ${ }^{32}$ Accordingly, they have been used as fluorescent labeling materials of drug delivery system (DDS). In our previous study, drug complexes with dual RE ions were successfully prepared. The synthesized complexes did not only increase the fluorescent intensity of the materials, but also greatly enhanced the accuracy of the drug tracing due to the existence of coordinate bond.

In this study, we aimed to generate RBC-like bifunctional particles as DDS carriers. To this end, the dual RE complex
$\mathrm{TbLa}_{3}(\mathrm{Bim})_{12}$ was synthesized as fluorescent material and $\mathrm{Fe}_{3} \mathrm{O}_{4}$ magnetic nanoparticles (MNPs) were used as the magnetic materials. We investigated the factors influencing the formation of RBC-like bifunctional particles in detail, including solvents, PLGA concentrations, collecting distances and flow rates of the solutions. The morphology, size distribution, structure, magnetic behaviour, fluorescent performance and hydrophobicity-hydrophilicity of the composite particles were studied. The effect of RBC-like $\mathrm{Fe}_{3} \mathrm{O}_{4} / \mathrm{TbLa}_{3}(\mathrm{Bim})_{12} / \mathrm{PLGA}$ composite particles at different concentrations on the viability of the adenocarcinoma human alveolar basal epithelial A549 cells was evaluated. The hemolytic activity and protein binding were also evaluated. The results suggested that the RBC-like bifunctional $\mathrm{Fe}_{3} \mathrm{O}_{4} / \mathrm{TbLa}_{3}(\mathrm{Bim})_{12} /$ PLGA composite particles could have potential application in drug delivery, targeting and tracking.

\section{Experimental}

\subsection{Materials}

PLGA $\left(M_{\mathrm{w}}=1 \times 10^{5}, \mathrm{LA}: \mathrm{GA}=85: 15\right)$ was purchased from Jinan Daigang Biotechnology Co., LTD (China). $\mathrm{La}_{2} \mathrm{O}_{3}$ (99\%), $\mathrm{Tb}_{4} \mathrm{O}_{7}(99 \%)$ and benzimidazole (Bim) were purchased from Sinopharm Chemical Reagent Co., LTD (China). $\mathrm{NaOH}, \mathrm{FeCl}_{3}$ $\cdot 6 \mathrm{H}_{2} \mathrm{O}$ and $\mathrm{FeCl}_{2} \cdot 4 \mathrm{H}_{2} \mathrm{O}$ were provided by Xilong Chemical Co., LTD (China). Hydrogen peroxide $\left(\mathrm{H}_{2} \mathrm{O}_{2}, 30 \%\right)$, hydrochloric acid ( $\mathrm{HCl})$, trichloromethane $\left(\mathrm{CHCl}_{3}\right)$, tetrahydrofuran (THF), dichloromethane $\left(\mathrm{CH}_{2} \mathrm{Cl}_{2}\right)$ and absolute ethylalcohol were provided by Beijing Chemical Works (China). Hexafluoroisopropanol (HFIP) was purchased from Aladdin Industrial Corporation. All reagents involved in this work were of analytical grade and directly used as-received without any further purification.

\subsection{Preparation of $\mathrm{Fe}_{3} \mathrm{O}_{4}$ MNPs}

$\mathrm{Fe}_{3} \mathrm{O}_{4}$ MNPs were obtained via a facile co-precipitation synthetic method. Briefly, $9.73 \mathrm{~g} \mathrm{FeCl} \cdot 6 \mathrm{H}_{2} \mathrm{O}, 3.98 \mathrm{~g} \mathrm{FeCl} \cdot 4 \mathrm{H}_{2} \mathrm{O}$ and $6.67 \mathrm{~g} \mathrm{NaOH}$ were added in $300 \mathrm{~mL}$ of deionized water, then stirred vigorously at $60{ }^{\circ} \mathrm{C}$ for $4 \mathrm{~h}$ and black precipitate was got. $0.03 \mathrm{M} \mathrm{HCl}$ was added in the black precipitate and the mixture was dispersed by ultrasound. Finally, the precipitate was washed several times with deionized water and dried under vacuum at $60{ }^{\circ} \mathrm{C}$ for $12 \mathrm{~h}$.

\subsection{Synthesis of RE complex of $\operatorname{TbLa}_{3}(\mathrm{Bim})_{12}$}

The synthesis of RE complex was carry out according to the method of Li, P. et al. ${ }^{33}$ To be specific, $1 \mathrm{~g} \mathrm{La}_{2} \mathrm{O}_{3}$ was dissolved in $10 \mathrm{~mL}$ concentrated $\mathrm{HCl}, 1 \mathrm{~g} \mathrm{~Tb} \mathrm{~Tb}_{7}$ was dissolved in $10 \mathrm{~mL}$ concentrated $\mathrm{HCl}$ with appropriate amount of $30 \% \mathrm{H}_{2} \mathrm{O}_{2}$. After evaporating of excess $\mathrm{HCl}$, the white powders $\mathrm{LaCl}_{3}$ and $\mathrm{TbCl}_{3}$ were obtained. Then $\mathrm{LaCl}_{3}, \mathrm{TbCl}_{3}$ and Bim with molar ratio of $1: 3: 12$ were dissolved in $80 \mathrm{~mL}$ ethanol. The mixture solutions were heated with thorough agitation at $60{ }^{\circ} \mathrm{C}$ for $6 \mathrm{~h}$ and separated by centrifugation. At last, the deposit was dried in the oven at $65{ }^{\circ} \mathrm{C}$ for $12 \mathrm{~h}$. 


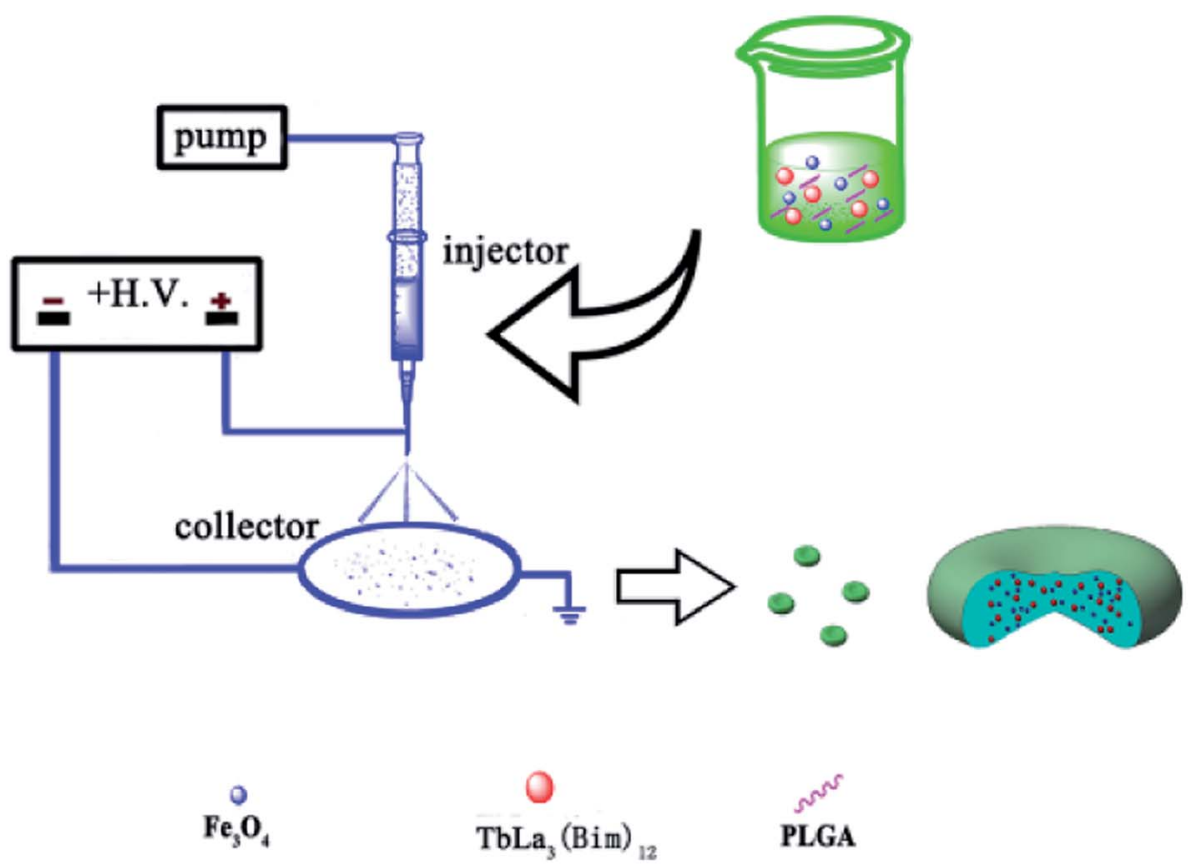

Fig. 1 Schematic illustration of the preparation of the RBC-like magnetic-fluorescent bifunctional $\mathrm{Fe}_{3} \mathrm{O}_{4} / \mathrm{TbLa}_{3}(\mathrm{Bim})_{12} / \mathrm{PLGA}$ composite particles.

2.4 Fabrication of RBC-like magnetic-fluorescent $\mathrm{Fe}_{3} \mathrm{O}_{4} /$ $\operatorname{TbLa}_{3}(\mathrm{Bim})_{12} /$ PLGA composite particles via electrospraying

To prepare the RBC-like $\mathrm{Fe}_{3} \mathrm{O}_{4} / \mathrm{TbLa}_{3}(\mathrm{Bim})_{12} / \mathrm{PLGA}$ composite particles, an electrospraying setup was employed. The experimental process was schematically illustrated in Fig. 1. The precursor components of PLGA, $\operatorname{TbLa}_{3}(\mathrm{Bim})_{12}$ and $\mathrm{Fe}_{3} \mathrm{O}_{4}$ MNPs were loaded into a $1 \mathrm{~mL}$ syringe with a stainless needle and the high voltage was set at 6-9 kV. An aluminum foil was used as the collector, which was placed at a certain distance away from the spinneret. The whole process was performed at room temperature. The influence of the experimental parameters, including the different solvents, PLGA concentration, collecting distance and flow rate of the solutions, were investigated during the formation of the RBC-like $\mathrm{Fe}_{3} \mathrm{O}_{4} / \mathrm{TbLa}_{3}(\mathrm{Bim})_{12} /$ PLGA composite particles.

2.4.1 The influence of solvent on $\mathrm{RBC}$-like $\mathrm{Fe}_{3} \mathrm{O}_{4} /$ $\mathrm{TbLa}_{3}(\mathbf{B i m})_{12} /$ PLGA composite particles. The different components, specifically $50 \mathrm{mg}$ of $\mathrm{Fe}_{3} \mathrm{O}_{4}$ MNPs, $125 \mathrm{mg}$ of PLGA and $100 \mathrm{mg}$ of $\mathrm{TbLa}_{3}(\mathrm{Bim})_{12}$ were dissolved in $5 \mathrm{~mL}$ of different solvents, including $\mathrm{CHCl}_{3}$, THF, $\mathrm{CH}_{2} \mathrm{Cl}_{2}$ and HFIP. After stirring for $4 \mathrm{~h}$, the precursor solutions were prepared. During electrospraying, the flow rate was $0.8 \mathrm{~mL} \mathrm{~h}^{-1}$ and the collecting distance was $15 \mathrm{~cm}$.

2.4.2 The influence of the PLGA concentration $(\%, w / v)$ on the $\mathrm{RBC}$-like $\mathrm{Fe}_{3} \mathrm{O}_{4} / \mathrm{TbLa}_{3}(\mathrm{Bim})_{12} /$ PLGA composite particles. The precursor solutions were prepared by dissolving $50 \mathrm{mg}$ of $\mathrm{Fe}_{3} \mathrm{O}_{4}$ MNPs, $100 \mathrm{mg}$ of $\mathrm{TbLa}_{3}(\mathrm{Bim})_{12}$ and different amounts of PLGA in $5 \mathrm{~mL}$ THF. After stirring for $4 \mathrm{~h}$, the parameters used for electrospraying were: flow rate at $0.8 \mathrm{~mL} \mathrm{~h}^{-1}$ and collecting distance of $15 \mathrm{~cm}$. The different PLGA concentrations were $0.625,1.25,2.5,3.75,5,7.5,10$ and $15 \%$, respectively.
2.4.3 The influence of the collecting distance on the RBClike $\mathrm{Fe}_{3} \mathrm{O}_{4} / \mathrm{TbLa}_{3}(\mathrm{Bim})_{12} /$ PLGA composite particles. The precursor solution with $2.5 \%$ PLGA was chosen to conduct the study in impact of the collecting distance. The evaluated collecting distances of electrospraying were 5, 15, 25, 35 and $45 \mathrm{~cm}$. The flow rate was $0.8 \mathrm{~mL} \mathrm{~h}^{-1}$.

2.4.4 The influence of flow rate of solutions on RBC-like $\mathrm{Fe}_{3} \mathrm{O}_{4} / \mathrm{TbLa}_{3}(\mathrm{Bim})_{12} /$ PLGA composite particles. The precursor solution with $2.5 \%$ PLGA was also used to conduct the study on the influence of flow rates. The evaluated flow rates of electrospraying were $0.10,0.40,1.60,2.40,3.20,4.80,6.00$ and $7.20 \mathrm{~mL}$ $\mathrm{h}^{-1}$. The collecting distance was $15 \mathrm{~cm}$.

2.4.5 The preparation of $\mathrm{RBC}$-like $\mathrm{Fe}_{3} \mathrm{O}_{4} / \mathrm{TbLa}_{3}(\mathrm{Bim})_{12} /$ PLGA composite particles containing different amounts of $\mathrm{Fe}_{3} \mathrm{O}_{4}$ and $\mathrm{TbLa}_{3}(\mathrm{Bim})_{12}$. The optimal electrospraying conditions for generating RBC-like particles were first determined. Then, we prepared several kinds of RBC-like particles with different contents of $\mathrm{Fe}_{3} \mathrm{O}_{4}$ MNPs and $\mathrm{TbLa}_{3}(\mathrm{Bim})_{12}$. The detailed dosages of materials are shown in Table 1.

Table 1 Compositions of the precursor solutions

\begin{tabular}{lllll}
\hline Sample & $\mathrm{Fe}_{3} \mathrm{O}_{4}(\mathrm{mg})$ & $\mathrm{TbLa}_{3}(\mathrm{Bim})_{12}(\mathrm{mg})$ & PLGA $(\mathrm{mg})$ & Solvent $(5 \mathrm{~mL})$ \\
\hline S1 & 50 & 100 & 125 & THF \\
S2 & 100 & 100 & 125 & THF \\
S3 & 150 & 100 & 125 & THF \\
S4 & 100 & 50 & 125 & THF \\
S5 & 100 & 100 & 125 & THF \\
S6 & 100 & 150 & 125 & THF
\end{tabular}




\subsection{Cell experiments}

2.5.1 Cell culture. A549 cells were obtained from Institute of Basic Medical Sciences (IBMS) of Chinese Academy of Medical Sciences (CAMS). Fetal bovine serum (FBS) was got from Zhejiang Tianhang Biotechnology Co., LTD. All other cell culture related reagents were purchased from Beijing Solarbio Science \& Technology Co., LTD. Cells were grown in normal RPMI-1640 culture medium with $10 \%$ FBS and 1\% penicillin/ streptomycin.

2.5.2 Cell viability. The in vitro cell viability was measured using a standard CCK-8 assay. A549 cells were seeded in a 96well plate at a density of 8000 cells per well and cultured in 1640 RPMI medium in $5 \% \mathrm{CO}_{2}$ at $37{ }^{\circ} \mathrm{C}$ for $24 \mathrm{~h}$. Then different concentrations $\left(7.81,31.25,62.5,125,250,500,1000 \mu \mathrm{g} \mathrm{mL}{ }^{-1}\right)$ of the RBC-like $\mathrm{Fe}_{3} \mathrm{O}_{4} / \mathrm{TbLa}_{3}(\mathrm{Bim})_{12} /$ PLGA particles (S6 in Table 1) were added to the cell culture medium, and incubated with the cells for $24 \mathrm{~h}$. After incubation, the medium containing the particles was removed from each well and $100 \mu \mathrm{L}$ of a solution, consisting of $10 \mu \mathrm{L}$ of the CCK-8 reagent solution and $90 \mu \mathrm{L}$ of cell culture medium, were added into each well and incubated for another $4 \mathrm{~h}$. The absorbance of each well in the plate was measured using a micro-plate reader at the wavelength of $450 \mathrm{~nm}$ and the data was used to calculate the cell viability.

2.5.3 Cell imaging. The cell imaging capability of RBC-like $\mathrm{Fe}_{3} \mathrm{O}_{4} / \mathrm{TbLa}_{3}(\mathrm{Bim})_{12} /$ PLGA particles was testified using A549 cells. Briefly, A549 cells were seeded in $60 \mathrm{~mm}$ Petri dishes with $4 \mathrm{~mL}$ RPMI-1640 culture medium and grew for $24 \mathrm{~h}$ as a monolayer. Then the cells were washed with PBS solution, and a certain amount of $\mathrm{Fe}_{3} \mathrm{O}_{4} / \mathrm{TbLa}_{3}(\mathrm{Bim})_{12} / \mathrm{PLGA}$ composite particles (S6 in Table 1) diluted in medium were added,
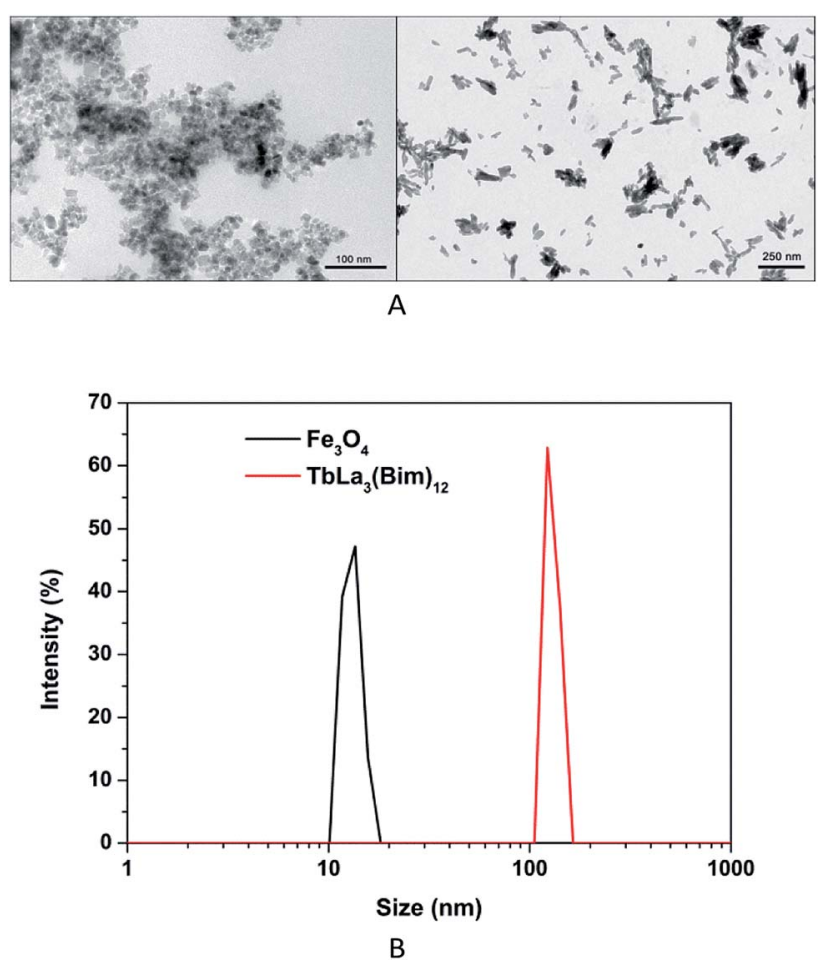

Fig. 2 (A) TEM images of $\mathrm{Fe}_{3} \mathrm{O}_{4}$ nanoparticles (left) and $\mathrm{TbLa}_{3}(\mathrm{Bim})_{12}$ (right); (B) size distribution of $\mathrm{Fe}_{3} \mathrm{O}_{4}$ nanoparticles and $\mathrm{TbLa}_{3}(\mathrm{Bim})_{12}$. incubating for $24 \mathrm{~h}$. The images were performed with a fluorescent microscope.

2.5.4 Magnetic responsiveness. In the magnetic responsive assay, a certain amount of the RBC-like $\mathrm{Fe}_{3} \mathrm{O}_{4} / \mathrm{TbLa}_{3}(\mathrm{Bim})_{12} /$ PLGA particles (S6 in Table 1) was incubated with A549 cells at $37{ }^{\circ} \mathrm{C}$ for $24 \mathrm{~h}$ with a ferrite magnet $(15 \times 88 \times 40 \mathrm{~mm}, 0.72 \mathrm{~T})$ placed near one edge of the Petri dish, and then imaged by fluorescent microscope.

\subsection{Hemolysis assay}

Hemolytic activity assay was performed according to previous reports. ${ }^{34}$ EDTA stabilized rabbit blood samples were freshly obtained from Peking University Health Science Centre (Beijing, China). First, blood was centrifuged at $2000 \mathrm{rpm}$ for $5 \mathrm{~min}$ and blood plasma and the surface layer were removed. The remaining RBC pellet was washed with PBS until the supernatant became transparent. 2\% RBC suspension was prepared by diluting $1 \mathrm{~mL}$ of RBC pellet in $49 \mathrm{~mL}$ PBS. Then, $0.8 \mathrm{~mL}$ of composite particles solutions in PBS at different concentrations (7.81-250 $\mu \mathrm{g} \mathrm{mL}^{-1}$ ) was added to $0.2 \mathrm{~mL}$ of $\mathrm{RBC}$ suspension. Also, $0.8 \mathrm{~mL}$ of water and PBS were added in $0.2 \mathrm{~mL}$ of RBC suspension as positive and negative control samples, respectively. All the samples were incubated at room temperature for $2 \mathrm{~h}$. The samples were slightly shaken once for every $30 \mathrm{~min}$. After $2 \mathrm{~h}$, the samples were centrifuged at $2000 \mathrm{rpm}$ and $100 \mathrm{~mL}$ of supernatants was transferred into a 96-well plate. Absorbance was measured with a micro-plate reader at $570 \mathrm{~nm}$. Hemolysis percentages of the RBCs were calculated using the following formula:

$\%$ Hemolysis $=($ abs of sample - abs of negative control $) /($ abs of positive control - abs of negative control)

\subsection{Non-specific protein binding}

Non-specific protein binding of RBC-like $\mathrm{Fe}_{3} \mathrm{O}_{4} / \mathrm{TbLa}_{3}(\mathrm{Bim})_{12} /$ PLGA particles was performed by BCA Protein Assay Kit. RBClike particles were incubated with RPMI-1640 culture medium with $10 \%$ FBS for $2 \mathrm{~h}$. Then, the particles were diluted by PBS at different concentrations (7.81-500 $\left.\mu \mathrm{g} \mathrm{mL}^{-1}\right)$. All the samples were washed in PBS 2 times to remove the soft corona. Then, samples were dispersed in BCA assay reagents and incubated for $30 \mathrm{~min}$ at $37^{\circ} \mathrm{C}$. The resulting solutions were then transferred into a 96-well plate, absorbance was measured at $562 \mathrm{~nm}$ using a micro-plate reader.

\subsection{Characterization}

The morphology of $\mathrm{Fe}_{3} \mathrm{O}_{4}, \mathrm{TbLa}_{3}(\mathrm{Bim})_{12}$ and $\mathrm{Fe}_{3} \mathrm{O}_{4} / \mathrm{TbLa}_{3}(\mathrm{Bim})_{12} /$ PLGA composite particles were observed by transmission electron microscope (TEM, JEM-1200EX, JEOL, Japan) and scanning electron microscope (SEM, Quanta ${ }^{\mathrm{TM}} 250$ FEG SEM, FEI, USA). The size distribution was measured by particle size analyzer (PSA, Zetasizer Nano S and Mastersizer 2000, Malvern, UK). The contact angle and surface tension of particles samples and precursor solutions were recorded using a contact angle measurement 

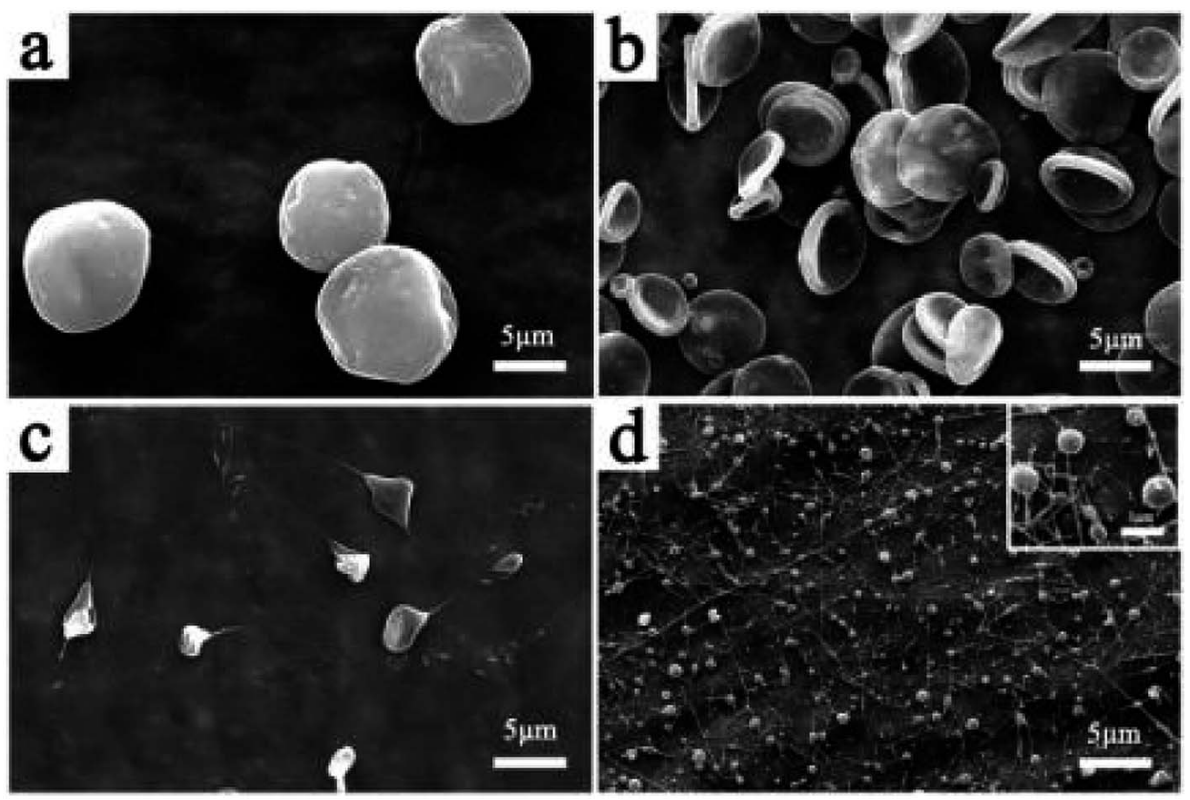

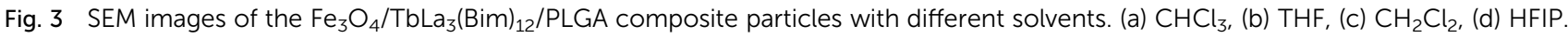

(JC2000FM, Powereach, China). The viscosity analysis of precursor solution was performed in a cone-plate viscometer (RST-CPS Touch Rheometer, Brookfield, USA). The stability of RBC-like $\mathrm{Fe}_{3} \mathrm{O}_{4} / \mathrm{TbLa}_{3}(\mathrm{Bim})_{12} / \mathrm{PLGA}$ composite particles was evaluated by UV-VIS-NIR spectrophotometer (UV-VIS-NIR, UV-3600, Shimadzu, Japan). The structure of Bim, $\mathrm{TbLa}_{3}(\mathrm{Bim})_{12}$, PLGA and RBC-like $\mathrm{Fe}_{3} \mathrm{O}_{4} / \mathrm{TbLa}_{3}(\mathrm{Bim})_{12} / \mathrm{PLGA}$ composite particles were measured by Fourier transform infrared spectroscopy (FTIR-650, Tianjin Gang Dong Technology Development Co., Ltd, China). The phases of $\mathrm{Fe}_{3} \mathrm{O}_{4}, \quad \mathrm{Bim}, \quad \mathrm{TbLa}_{3}(\mathrm{Bim})_{12}$ and $\mathrm{Fe}_{3} \mathrm{O}_{4} / \mathrm{TbLa}_{3}(\mathrm{Bim})_{12} / \mathrm{PLGA}$ composite particles were identified by a X-ray diffraction analysis (XRD, D/MAX-2500, Rigaku, Japan). The magnetic performances of samples were measured by a vibrating sample magnetometer (VSM, Laker Shore 7307, USA) and fluorescent microscope (OLYMBUS, IX73, Japan). The fluorescent properties of samples were investigated by fluorescence spectroscopy (FS5, Edinburgh, UK) and fluorescent microscope. The absorbance was evaluated by a micro-plate reader (Multiskan MK3, Thermo, USA).

\subsection{Statistical analysis}

Results were expressed as means \pm standard deviation (SD) for repetitive tests. The statistical significance of results between groups was carried out by one-way ANOVA. The statistical analysis was performed with the software SPSS 19.0 at a confidence level of $95 \%$. Differences were considered to be statistically significant for values of $p<0.05$.

\section{Results and discussion}

3.1 Fabrication of the RBC-like $\mathrm{Fe}_{3} \mathrm{O}_{4} / \mathrm{TbLa}_{3}(\mathrm{Bim})_{12} /$ PLGA composite particles

The size and size distribution of precursors $\left(\mathrm{Fe}_{3} \mathrm{O}_{4}\right.$ and $\operatorname{TbLa}_{3}(\mathrm{Bim})_{12}$ ) were examined by TEM and PSA. The TEM image
(Fig. 2A) and size intensity (Fig. 2B) showed the uniform morphologies of the two precursors. The average hydrodynamic diameter of $\mathrm{Fe}_{3} \mathrm{O}_{4}$ and $\mathrm{TbLa}_{3}(\mathrm{Bim})_{12}$ was 13.4 and $123.2 \mathrm{~nm}$, respectively.

The morphology and size of PLGA particles can be greatly influenced by various electrospraying parameters, including the solvent, PLGA concentration, collecting distance and flow rate of the solutions.

3.1.1 The influence of solvent on the morphology of the RBC-like $\mathrm{Fe}_{3} \mathrm{O}_{4} / \mathrm{TbLa}_{3}(\mathrm{Bim})_{12} /$ PLGA composite particles. The precursor solutions with $125 \mathrm{mg}$ PLGA, $50 \mathrm{mg} \mathrm{Fe}_{3} \mathrm{O}_{4}$ and $100 \mathrm{mg}$ $\mathrm{TbLa}_{3}(\mathrm{Bim})_{12}$ were electrosprayed with different solvents. The SEM images of the different samples were shown in Fig. 3. Only spherical particles could be prepared when $\mathrm{CHCl}_{3}$ was chosen as solvent (Fig. 3a), while RBC-like particles could be successfully obtained with THF (Fig. 3b). Irregular particles with a short fibres tail were produced using $\mathrm{CH}_{2} \mathrm{Cl}_{2}$ (Fig. 3c), and small size beads and fibres were prepared with HFIP (Fig. 3d). The difference in the surface tension of the precursor solutions might play an important role in the formation of different shapes. The surface tensions of the four precursor solutions were measured, as shown in Table 2. The jet flow was more likely change to spherical particles, with high surface tension, when the solution was $\mathrm{CHCl}_{3}$. As the surface tension of THF decreased compared with $\mathrm{CHCl}_{3}$, the spheres collapsed, thereby forming RBC particles. When the value of the surface tension

Table 2 The surface tension of the precursor solutions with different solvents

\begin{tabular}{lllll}
\hline & $\mathrm{CHCl}_{3}$ & THF & $\mathrm{CH}_{2} \mathrm{Cl}_{2}$ & HFIP \\
\hline Surface tension & 24.5 & 22.0 & 20.7 & $5.8\left(\mathrm{mN} \mathrm{m}^{-1}\right)$
\end{tabular}



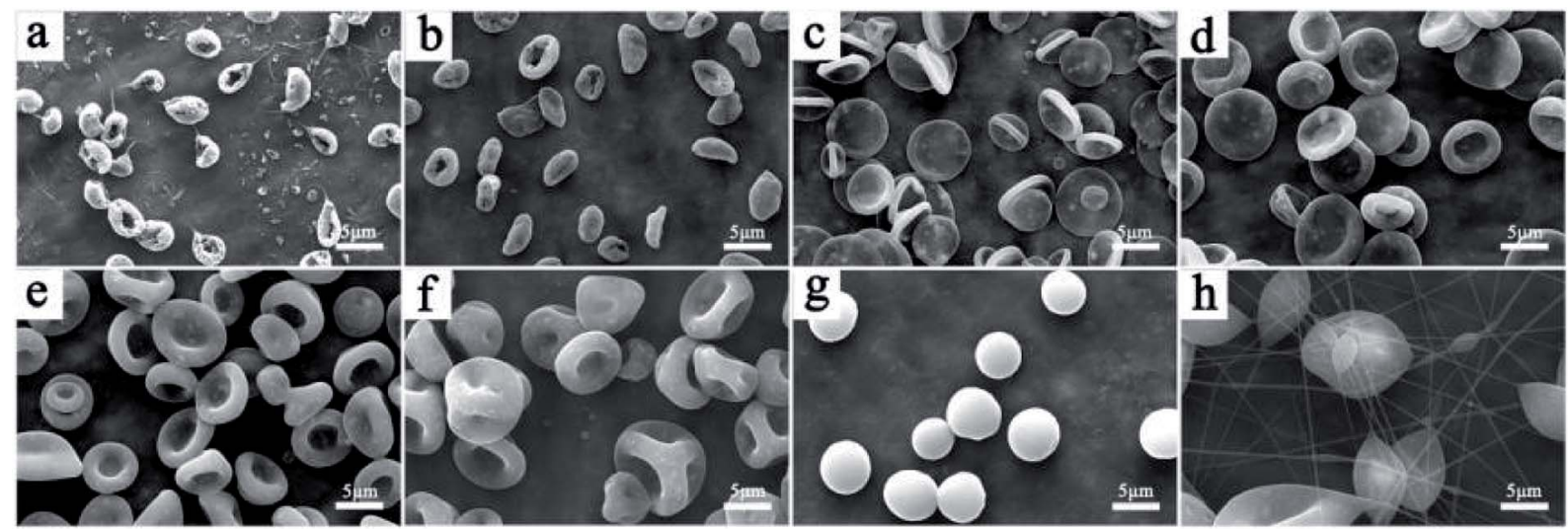

A

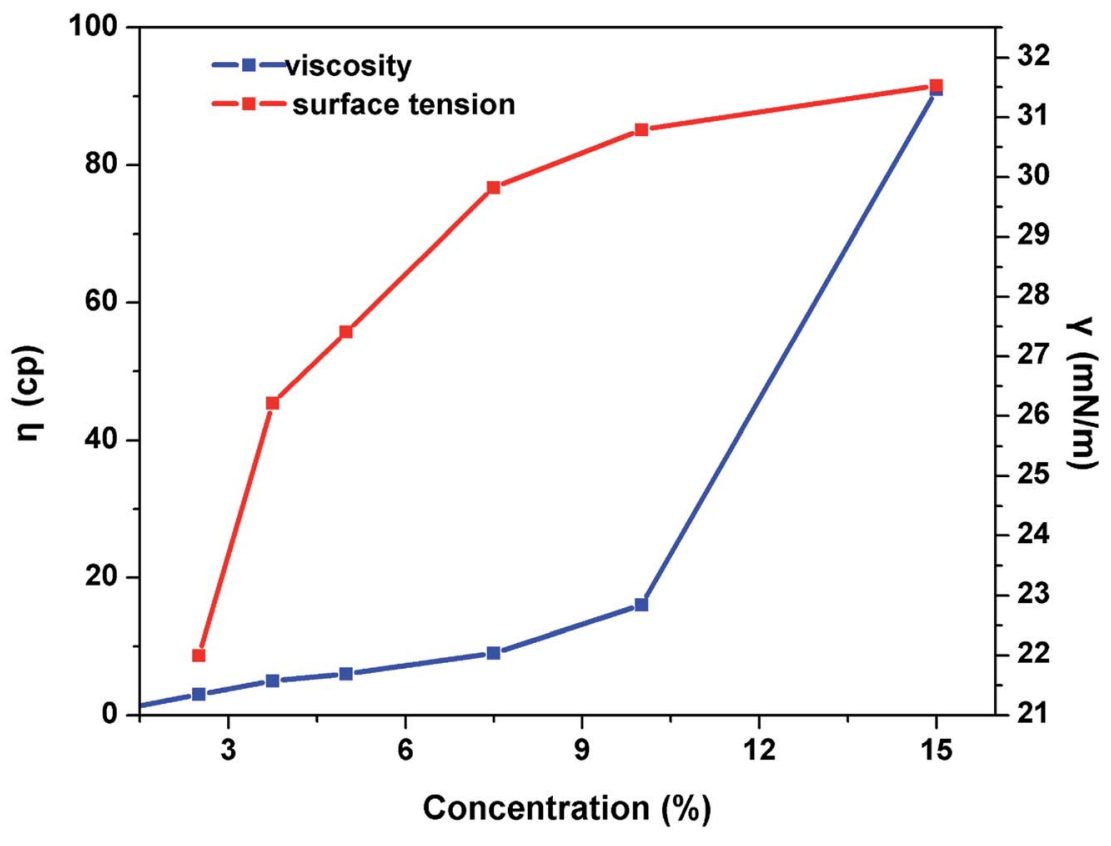

B

Fig. 4 (A) SEM images of the $\mathrm{Fe}_{3} \mathrm{O}_{4} / \mathrm{TbLa}_{3}(\mathrm{Bim})_{12} / \mathrm{PLGA}$ composite particles under different PLGA concentrations (a) $0.625 \%$, (b) $1.25 \%$, (c) $2.5 \%$, (d) $3.75 \%$, (e) $5 \%$, (f) $7.5 \%$, (g) $10 \%$, (h) $15 \%$; (B) the relationship of the surface tension and viscosity of the solutions with the change of PLGA concentration.

was lower than the electrostatic repulsion, fibres were easier to produce. A few short fibres appeared along the irregular particles when using $\mathrm{CH}_{2} \mathrm{Cl}_{2}$ as solution, and more fibres could be observed when HFIP, with low surface tension, was used.

3.1.2 The influence of the PLGA concentration on the RBClike $\mathrm{Fe}_{3} \mathrm{O}_{4} / \mathrm{TbLa}_{3}(\mathrm{Bim})_{12} / \mathbf{P L G A}$ composite particles. The effect of the PLGA concentration on the morphology of the RBC-like particles was investigated. Precursor solutions containing $50 \mathrm{mg} \mathrm{Fe}_{3} \mathrm{O}_{4}$ and $100 \mathrm{mg} \mathrm{TbLa} 3(\mathrm{Bim})_{12}$ were electrosprayed with different amounts of PLGA. The SEM images of the particles with different PLGA concentrations were shown in Fig. 4A. At the concentration of $0.625 \%$ PLGA, irregular particles were generated. With the increase of the PLGA concentration, more and more regular particles appeared. The RBC-like particles began to form at $2.5 \%$. When the concentration reached at $7.5 \%$, concave particles with three sides were fabricated. At $10 \%$, a large number of spherical particles were obtained. As concentrations beyond 15\%, large spindle-shaped particles accompanying those with the appearance of fibres were produced. The result was consistent with a study on the transition from the roundness of a bead to oval shape..$^{35}$ The optimal concentration range to produce $\mathrm{RBC}$-like particles is from $2.5 \%$ to $5 \%$. 

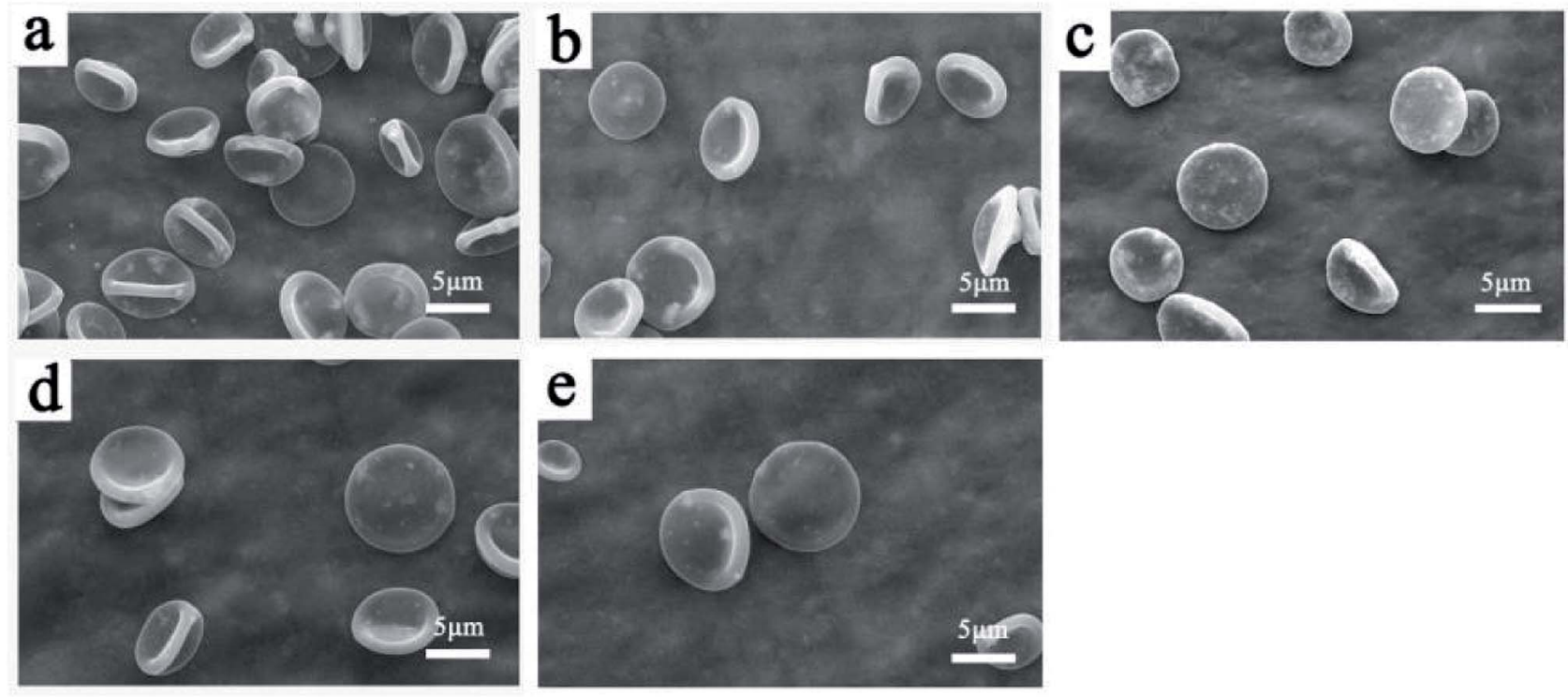

A
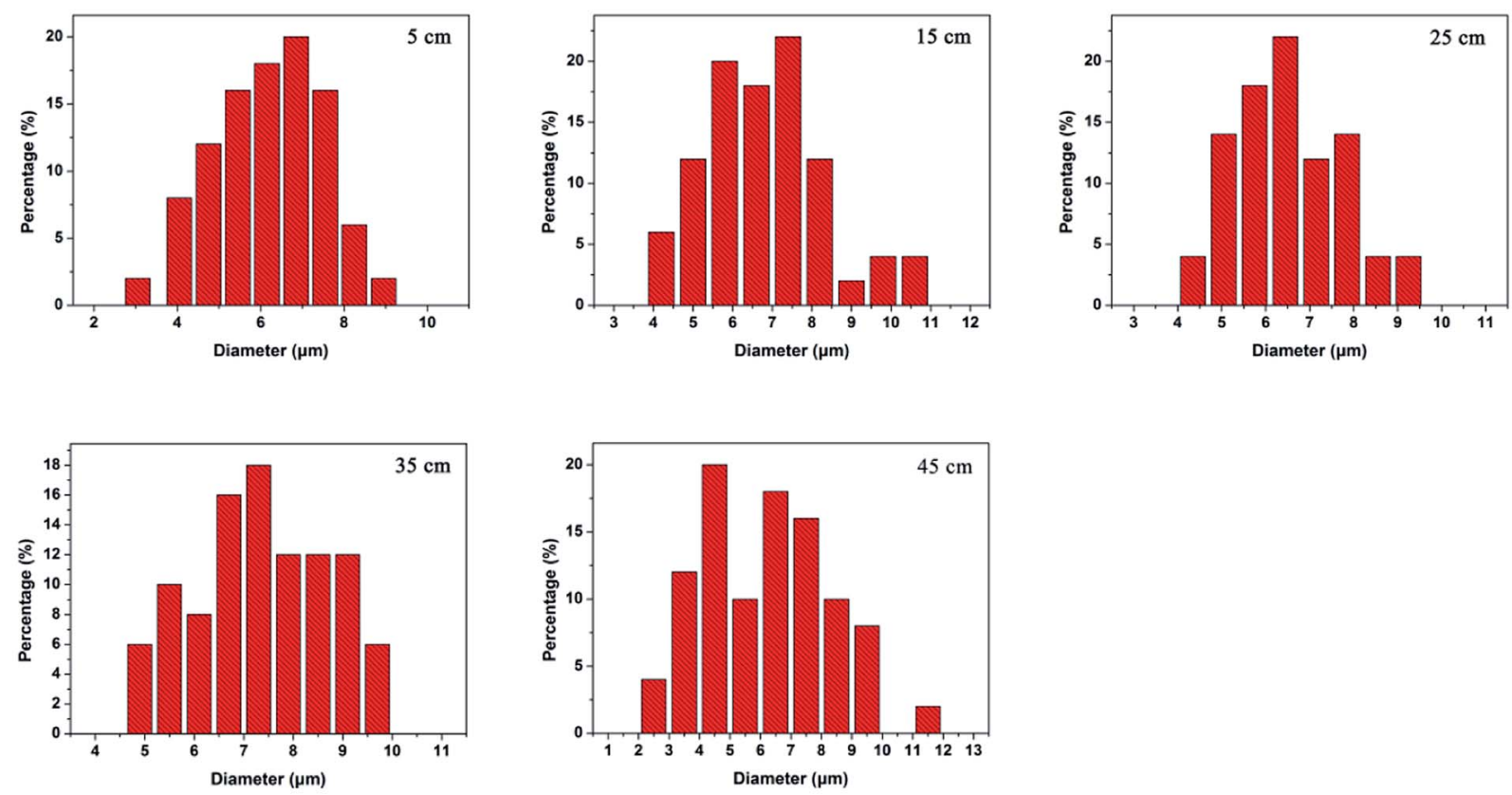

B

Fig. 5 (A) SEM images of the $\mathrm{Fe}_{3} \mathrm{O}_{4} / \mathrm{TbLa}_{3}(\mathrm{Bim})_{12} / \mathrm{PLGA}$ composite particles at different distances. (a) $5 \mathrm{~cm}$, (b) $15 \mathrm{~cm}$, (c) $25 \mathrm{~cm}$, (d) $35 \mathrm{~cm}$, (e) $45 \mathrm{~cm}$; (B) the particle size distribution at different collecting distances.

The viscosity and surface tension of the solutions with different PLGA concentrations were shown in Fig. 4B. In areas with low PLGA concentration, the viscosity of solutions was very small, the tangling of molecular chains was insufficient or there was even a lack entanglement, which easily caused the fracture of molecular chains, as a result, the jet flow was likely to form irregular particles rather than fibres. However, as the surface tension gradually increased, occupying the leading position, it contributed to the formation of regular particles. Accordingly, from $2.5 \%$ to $5 \%$, RBC particles were obtained. With higher surface tension at $7.5 \%$ PLGA concentration, three-side concave particles appeared. When the PLGA concentration reached at $10 \%$, the surface tension continued to increase, while the viscosity increased at low magnitude, and then the spherical 

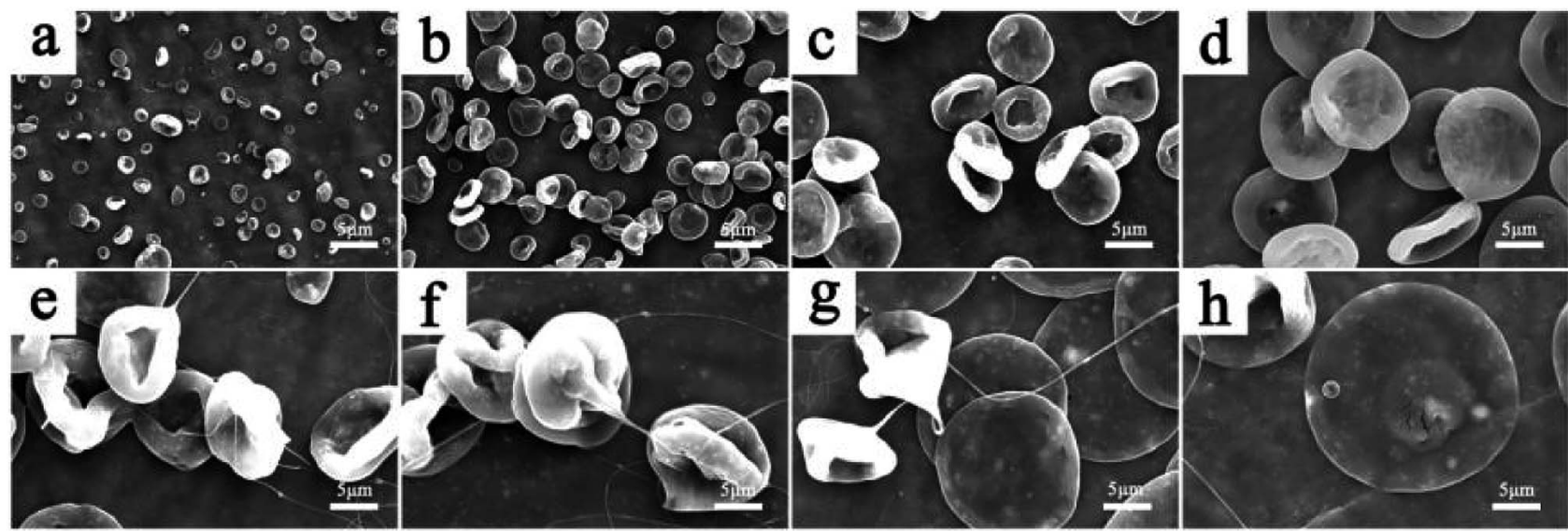

Fig. $6 \mathrm{SEM}$ images of the $\mathrm{Fe}_{3} \mathrm{O}_{4} / \mathrm{TbLa}_{3}(\mathrm{Bim})_{12} / \mathrm{PLGA}$ composite particles at different flow rates. (a) $0.1 \mathrm{~mL} \mathrm{~h}^{-1}$, (b) $0.4 \mathrm{~mL} \mathrm{~h}{ }^{-1}$, (c) $1.6 \mathrm{~mL} \mathrm{~h}^{-1}$, (d) $2.4 \mathrm{~mL} \mathrm{~h}^{-1}$, (e) $3.2 \mathrm{~mL} \mathrm{~h}^{-1}$, (f) $4.8 \mathrm{~mL} \mathrm{~h}^{-1}$, (g) $6.0 \mathrm{~mL} \mathrm{~h}^{-1}$, (h) $7.2 \mathrm{~mL} \mathrm{~h}^{-1}$.

particles formed easily. At $15 \%$ PLGA concentration, the viscosity of the solutions increased dramatically, whereas the rising trend of the surface tension slowed down. At high PLGA concentration, it is observed that spindled-shape particles and even fibres were produced.

3.1.3 The influence of the collecting distance on $\mathrm{Fe}_{3} \mathrm{O}_{4}$ / $\mathrm{TbLa}_{3}(\mathrm{Bim})_{12} /$ PLGA composite particles. The influence of different collecting distances on the PLGA particle morphology and size was also investigated. The precursor of the $125 \mathrm{mg}$ PLGA, $50 \mathrm{mg} \mathrm{Fe}_{3} \mathrm{O}_{4}$ and $100 \mathrm{mg} \mathrm{TbLa} 3(\mathrm{Bim})_{12}$ in THF were electrosprayed at the collecting distances from 5 to $45 \mathrm{~cm}$. The SEM images and size distribution of the particles were shown in Fig. 5A and B. The images revealed that RBC-like particles could be prepared at the distances from 5 to $45 \mathrm{~cm}$, which suggested that the collecting distance had little effect on the morphology of the RBC-like particles, but rather had its effect on the particles size distribution. The diameter of 50 particles from each sample was measured with the software Nano Measurer 1.2. In the distance from 5 to $35 \mathrm{~cm}$ (Fig. $5 \mathrm{~A}(\mathrm{a}-\mathrm{c}))$, the average particles size became larger as the collecting distance increased, with an average diameter of $6.21,6.75,6.83$ and $7.37 \mu \mathrm{m}$, respectively. With the increase of the distance, the electric field force declined, which weakened the stretching of the jet flow and, consequently, resulted in the increase of the diameter. However, at the distance of $45 \mathrm{~cm}$, the average particles size decreased to $6.19 \mu \mathrm{m}$. When the distance reached $45 \mathrm{~cm}$, more time was required for the jet flow to stretch sufficiently, and the solvent could completely volatilize, then the smaller particles could be observed, but with a more uneven distribution.

3.1.4 The influence of the solution flow rates on the $\mathrm{Fe}_{3} \mathrm{O}_{4} /$ $\mathrm{TbLa}_{3}(\mathrm{Bim})_{12} /$ PLGA composite particles. The solution of $2.5 \%$ PLGA in THF, $50 \mathrm{mg} \mathrm{Fe}_{3} \mathrm{O}_{4}$ and $100 \mathrm{mg} \mathrm{TbLa}{ }_{3}(\mathrm{Bim})_{12}$ was electrosprayed at different flow rates and the SEM images of the samples were shown in Fig. 6. The RBC-like particles appeared at the rate of $0.10 \mathrm{~mL} \mathrm{~h}^{-1}$ as shown in Fig. 6, where some irregular particles can also be observed and the particles size is uniformly distributed. The regular RBC-like particles could be obtained at the rate of $0.4,1.6$, and $2.4 \mathrm{~mL} \mathrm{~h}^{-1}$, and the diameter of particles increased with increasing flow rate, as shown in Fig. 6b-d. However, the RBC-like PLGA particles became irregular again and were accompanied with a few fibres when the flow rate changed from 3.2 to $6.0 \mathrm{~mL} \mathrm{~h}^{-1}$, and there even appeared particles with flat shape at $7.2 \mathrm{~mL} \mathrm{~h}^{-1}$. The high flow rate might lead to the charge accumulation of jet-cone, increasing the jet instability and causing the irregular particles and fibre to appear. ${ }^{36}$

To obtain good RBC-like particles, the following electrospraying factors were chosen in the subsequent study: $2.5 \%$ PLGA concentration, THF as solvent, collecting distance of $15 \mathrm{~cm}$ and flow rate at $0.8 \mathrm{~mL} \mathrm{~h}^{-1}$. The size distribution of RBClike particles was shown in Fig. 7. The average hydrodynamic diameter was $6.5 \mu \mathrm{m}$.

\subsection{Stability evaluation under ambient condition}

The stability of RBC-like $\mathrm{Fe}_{3} \mathrm{O}_{4} / \mathrm{TbLa}_{3}(\mathrm{Bim})_{12} /$ PLGA particles in PBS (1 $\left.\mathrm{mg} \mathrm{mL}^{-1}\right)$ was examined by UV-VIS-NIR

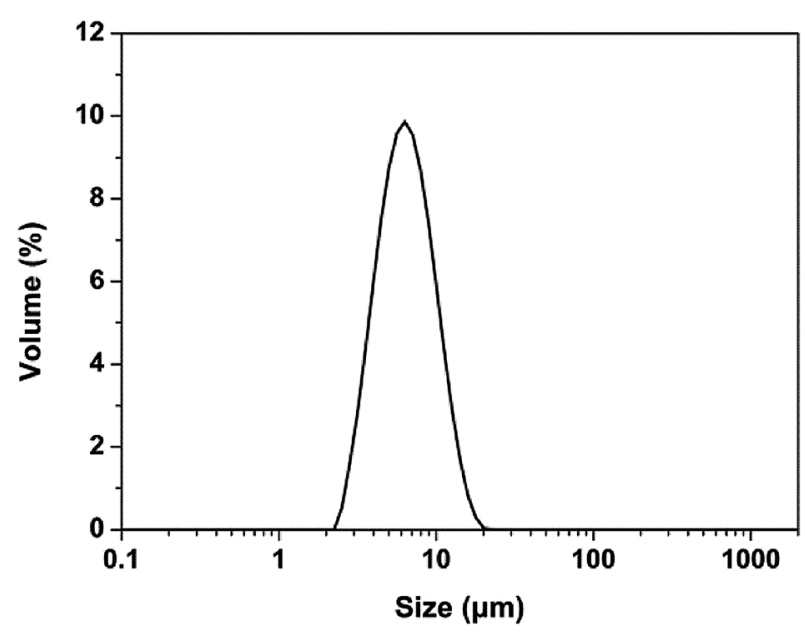

Fig. 7 Size distribution of RBC-like $\mathrm{Fe}_{3} \mathrm{O}_{4} / \mathrm{TbLa}_{3}(\mathrm{Bim})_{12} / \mathrm{PLGA}$ composite particles. 


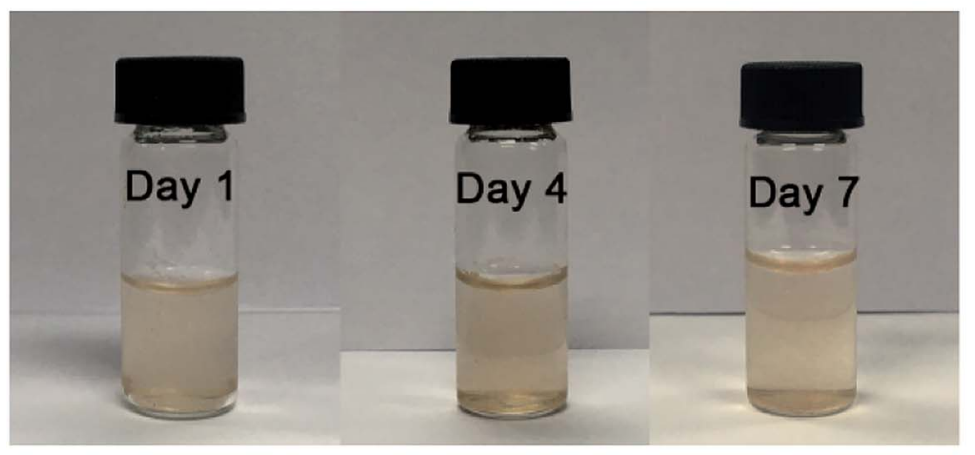

A

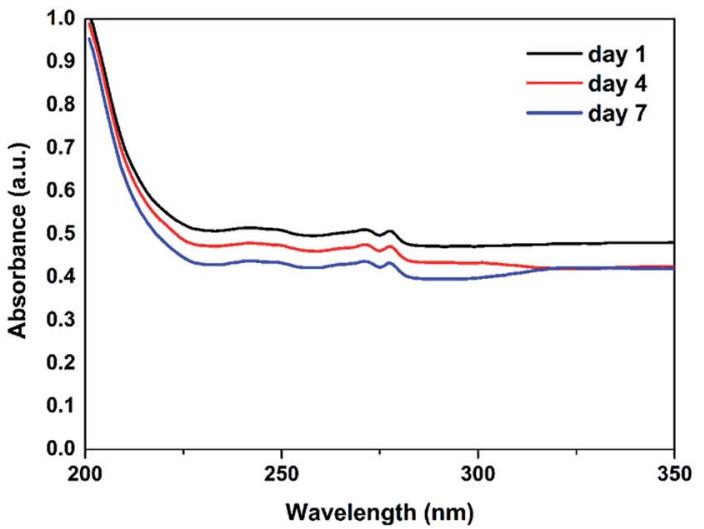

B

Fig. 8 Stability evaluation under ambient condition. (A) Photographs and (B) absorption spectra of RBC-like $\mathrm{Fe}_{3} \mathrm{O}_{4} / \mathrm{TbLa}_{3}(\mathrm{Bim}){ }_{12} / \mathrm{PLGA}$ particles with the same concentration after storing in PBS for different periods of time.

spectrophotometer at predetermined time intervals $(1,4$ and 7 days). As shown in Fig. 8A, the colour of sample solution was similar and there was no significant change appeared. The UV absorbance spectra (Fig. 8B) showed there were several weak absorption peaks between 240 and $280 \mathrm{~nm}$. Along with the time, the absorbance intensities of RBC-like $\mathrm{Fe}_{3} \mathrm{O}_{4} / \mathrm{TbLa}_{3}(\mathrm{Bim})_{12} /$ PLGA particles slightly decreased, which demonstrated that the RBC-like particles were biodegradable.

\subsection{Infrared analysis}

The FTIR spectra of Bim, $\mathrm{TbLa}_{3}(\mathrm{Bim})_{12}$, PLGA and $\mathrm{Fe}_{3} \mathrm{O}_{4} /$ $\mathrm{TbLa}_{3}(\mathrm{Bim})_{12} / \mathrm{PLGA}$ were displayed in Fig. 9. The peaks of Bim at 3061, 1454.55, 1409.93, 1243.89 and $748.25 \mathrm{~cm}^{-1}$ represent the $\mathrm{C}-\mathrm{H}$ stretching vibration of the benzene ring, the $\mathrm{C}=\mathrm{N}$ stretching vibration, the in-plane deformation of the benzimidazole ring, the in-plane $\mathrm{C}-\mathrm{H}$ deformation and the out-of-plane $\mathrm{C}-\mathrm{H}$ bending vibration, respectively. The infrared spectrum of $\mathrm{TbLa}_{3}(\mathrm{Bim})_{12}$ was distinctly different

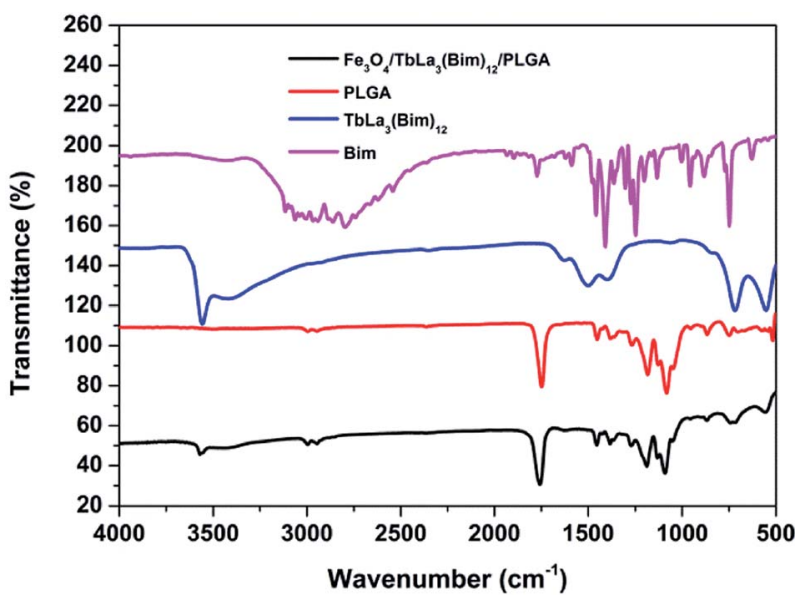

Fig. 9 FTIR spectra of Bim, $\mathrm{TbLa}_{3}(\mathrm{Bim})_{12}, \mathrm{PLGA}$ and RBC-like $\mathrm{Fe}_{3} \mathrm{O}_{4} /$ $\mathrm{TbLa}_{3}(\mathrm{Bim})_{12} / \mathrm{PLGA}$ composite particles. from the spectrum of the Bim ligand. The peak at $3061 \mathrm{~cm}^{-1}$ disappeared, while the peaks at $1409.93 \mathrm{~cm}^{-1}$ and $1243.89 \mathrm{~cm}^{-1}$ red-shifted to $1504.11 \mathrm{~cm}^{-1}$ and $1398.09 \mathrm{~cm}^{-1}$ and the peak at $748.25 \mathrm{~cm}^{-1}$ blue-shifted to $720.36 \mathrm{~cm}^{-1}$. The shifts of the above peaks indicated that the Bim ligand was successfully bound to $\mathrm{Tb}^{3+}$ and $\mathrm{La}^{3+}$. Additionally, a wide $\mathrm{O}-\mathrm{H}$ stretching vibration absorption peak located at $3555 \mathrm{~cm}^{-1}$ occurred, which indicated that there was crystal water generated in the $\mathrm{TbLa}_{3}(\mathrm{Bim})_{12}$. Compared with $\mathrm{TbLa}_{3}(\mathrm{Bim})_{12}$, a strong peak in the spectrum of $\mathrm{Fe}_{3} \mathrm{O}_{4} /$ $\mathrm{TbLa}_{3}(\mathrm{Bim})_{12} / \mathrm{PLGA}$ at $1761.58 \mathrm{~cm}^{-1}$ was due to the $\mathrm{C}=\mathrm{O}$ stretching vibration present in PLGA, and the absorption peaks at $1184.55 \mathrm{~cm}^{-1}$ and $1096.71 \mathrm{~cm}^{-1}$ were assigned to the $\mathrm{C}-\mathrm{O}$ stretching vibration of PLGA. Some peaks that appeared in $\mathrm{TbLa}_{3}(\mathrm{Bim})_{12}$ were not observed in the $\mathrm{Fe}_{3} \mathrm{O}_{4} / \mathrm{TbLa}_{3}(-$ $\mathrm{Bim})_{12} / \mathrm{PLGA}$, which is probably covered by the strong signals of PLGA. Overall, $\mathrm{TbLa}_{3}(\mathrm{Bim})_{12}$ was successfully encapsulated by the RBC-like PLGA particles.

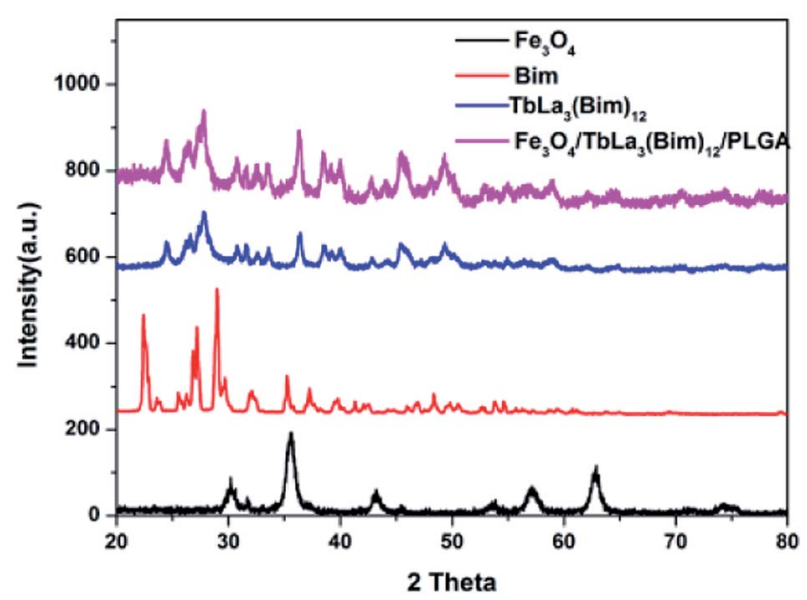

Fig. 10 XRD patterns of $\mathrm{Fe}_{3} \mathrm{O}_{4}$ MNPs, Bim, $\mathrm{TbLa}_{3}(\mathrm{Bim})_{12}$ and the RBClike $\mathrm{Fe}_{3} \mathrm{O}_{4} / \mathrm{TbLa}_{3}(\mathrm{Bim})_{12} / \mathrm{PLGA}$ composite particles. 


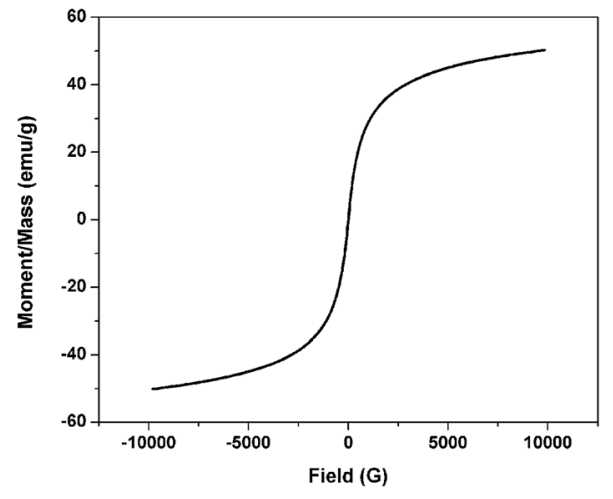

A

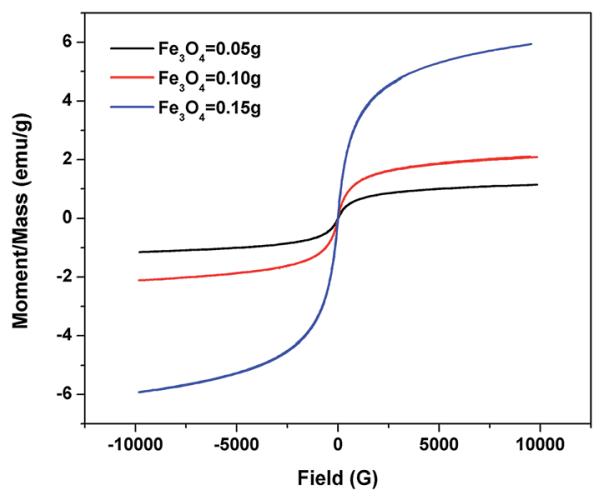

B

Fig. 11 (A) Hysteresis loop of pure $\mathrm{Fe}_{3} \mathrm{O}_{4}$; (B) hysteresis loops of the $\mathrm{RBC}$-like $\mathrm{Fe}_{3} \mathrm{O}_{4} / \mathrm{TbLa}_{3}(\mathrm{Bim})_{12} /$ PLGA composite particles with different amounts of $\mathrm{Fe}_{3} \mathrm{O}_{4}$.

\subsection{XRD analysis}

The XRD patterns of $\mathrm{Fe}_{3} \mathrm{O}_{4}$, Bim, $\mathrm{TbLa}_{3}(\mathrm{Bim})_{12}$ and the RBC-like $\mathrm{Fe}_{3} \mathrm{O}_{4} / \mathrm{TbLa}_{3}(\mathrm{Bim})_{12} /$ PLGA composite particles were shown in Fig. 10. For the $\mathrm{Fe}_{3} \mathrm{O}_{4}$ MNPs, all the intense peaks could be well indexed to the cubic phase of $\mathrm{Fe}_{3} \mathrm{O}_{4}$ (JCPDS no. 74-0748), and no other characteristic peaks were observed, indicating no impurities like $\mathrm{FeO}(\mathrm{OH})$ and $\mathrm{Fe}_{2} \mathrm{O}_{3}$ were produced. The spectrum of $\mathrm{TbLa}_{3}(\mathrm{Bim})_{12}$ had weaker crystalline peaks than those of Bim, suggesting that the reaction of $\mathrm{Tb}^{3+}, \mathrm{La}^{3+}$ and Bim had already been completed. For $\mathrm{Fe}_{3} \mathrm{O}_{4} / \mathrm{TbLa}_{3}(\mathrm{Bim})_{12} / \mathrm{PLGA}$, the diffraction pattern included peaks of both $\mathrm{Fe}_{3} \mathrm{O}_{4}$ MNPs and $\mathrm{TbLa}_{3}(\mathrm{Bim})_{12}$, indicating that they have been successfully encapsulated by PLGA.

\subsection{The magnetic properties of the $\mathrm{RBC}$-like $\mathrm{Fe}_{3} \mathrm{O}_{4} /$ $\mathrm{TbLa}_{3}(\mathrm{Bim})_{12} /$ PLGA composite particles}

To study the magnetic properties of the $\mathrm{Fe}_{3} \mathrm{O}_{4} / \mathrm{TbLa}_{3}(\mathrm{Bim})_{12} /$ PLGA particles and the influence of different amounts of $\mathrm{Fe}_{3} \mathrm{O}_{4}$ MNPs in the particles, the hysteresis loops of the $\mathrm{Fe}_{3} \mathrm{O}_{4}$ MNPs and RBC-like $\mathrm{Fe}_{3} \mathrm{O}_{4} / \mathrm{TbLa}_{3}(\mathrm{Bim})_{12} /$ PLGA particles under an applied field of $10 \mathrm{kOe}$ were shown in Fig. 11. The saturation magnetization of the pure $\mathrm{Fe}_{3} \mathrm{O}_{4}$ MNPs was $51 \mathrm{emu} \mathrm{g}^{-1}$. The magnetic properties of the RBC-like $\mathrm{Fe}_{3} \mathrm{O}_{4} / \mathrm{TbLa}_{3}(\mathrm{Bim})_{12} / \mathrm{PLGA}$ composite particles depended on the contents of the magnetic substance in the particles. When the contents of the $\mathrm{Fe}_{3} \mathrm{O}_{4}$
MNPs varied from $50 \mathrm{mg}$ to $150 \mathrm{mg}$, the value of saturation magnetization increased from 1.14 to $5.94 \mathrm{emu}^{-1}$. These results indicated that the composite particles had adequate magnetic response for biomedical applications, and magnetic response could be tuned by adding various amounts of $\mathrm{Fe}_{3} \mathrm{O}_{4}$ MNPs.

The magnetic response capability of particles (S6 in Table 1) was tested by adding particles to A549 cell culture medium while using a magnet. The results visualized with a fluorescent microscope were shown in Fig. 12. Before adding the magnet, it was observed that particles were uniformly distributed in a Petri dish. After placing a magnet in the side of the Petri dish, more particles appeared at the side near the magnet and, on the contrary, a few particles sparsely distributed at the other side. The magnetism of the particles still existed even when incubated with cells for 1 or more days, suggesting the possibility that the RBC-like $\mathrm{Fe}_{3} \mathrm{O}_{4} / \mathrm{TbLa}_{3}(\mathrm{Bim})_{12} /$ PLGA composite particles can be additionally applied in magnetic targeting in vivo.

\subsection{The fluorescent properties of the $\mathrm{RBC}$-like $\mathrm{Fe}_{3} \mathrm{O}_{4} /$ $\mathrm{TbLa}_{3}(\mathrm{Bim})_{12} /$ PLGA composite particles}

The fluorescent properties of the RBC-like $\mathrm{Fe}_{3} \mathrm{O}_{4} / \mathrm{TbLa}_{3}(\mathrm{Bim})_{12} /$ PLGA composite particles were studied at the excitation wavelength of $350 \mathrm{~nm}$. The emission spectra of RBC-like particles encapsulating different amounts of $\mathrm{TbLa}_{3}(\mathrm{Bim})_{12}$ were displayed in Fig. 13A. The fluorescent intensity was enhanced by
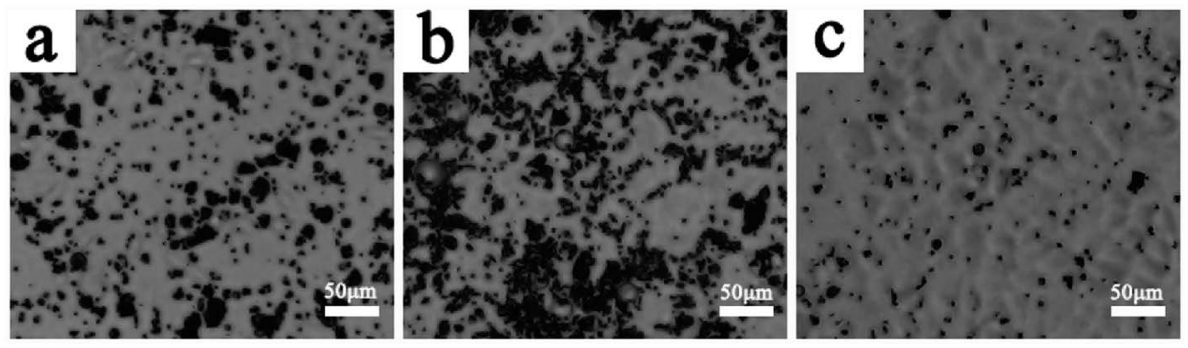

Fig. 12 Fluorescent microscope images of $\mathrm{A} 549$ cells incubated with the RBC-like $\mathrm{Fe}_{3} \mathrm{O}_{4} / \mathrm{TbLa}_{3}(\mathrm{Bim})_{12} /$ PLGA composite particles under the effect of a magnet. (a) Without magnet, (b) near magnet, (c) far from magnet. 


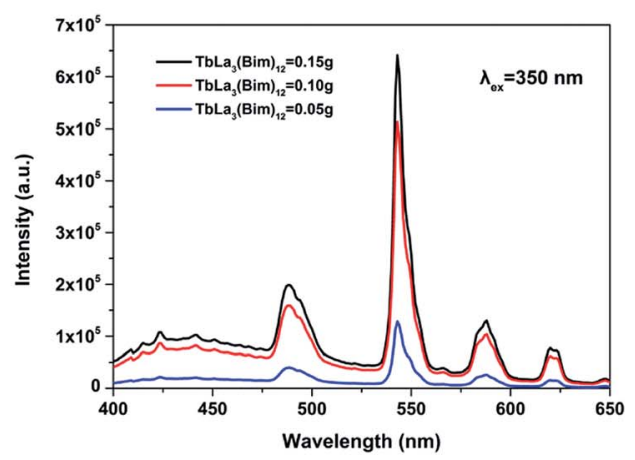

A
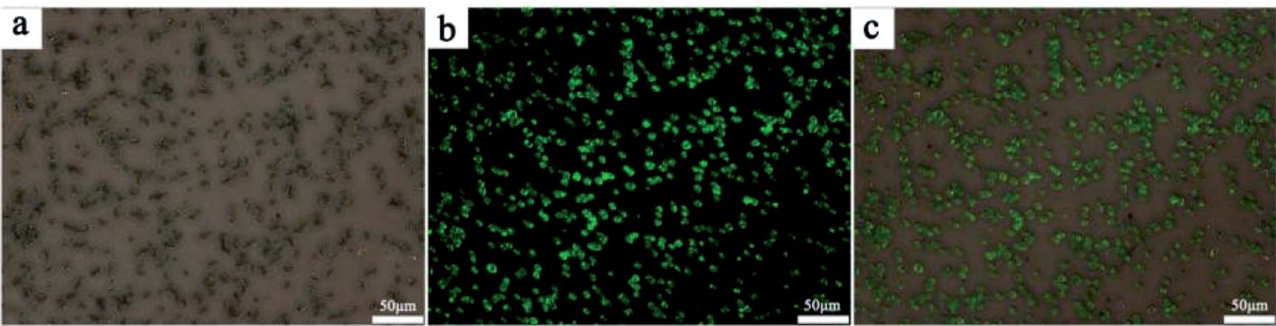

B

Fig. 13 (A) Emission spectra of the RBC-like $\mathrm{Fe}_{3} \mathrm{O}_{4} / \mathrm{TbLa}_{3}(\mathrm{Bim})_{12} / \mathrm{PLGA}$ composite particles with different amounts of TbLa $(\mathrm{Bim})_{12}$; $(\mathrm{B})$ fluorescent microscope images of the $\mathrm{RBC}$-like $\mathrm{Fe}_{3} \mathrm{O}_{4} / \mathrm{TbLa}_{3}(\mathrm{Bim})_{12} / \mathrm{PLGA}$ composite particles. (a) Bright-field image, (b) fluorescent image (c) the overlay image.

the increase of the content of $\mathrm{TbLa}_{3}(\mathrm{Bim})_{12}$. When the content of $\mathrm{TbLa}_{3}(\mathrm{Bim})_{12}$ was $50 \mathrm{mg}$, the particles exhibited the lowest fluorescent intensity. Then, the fluorescent intensity increased markedly when the content of $\mathrm{TbLa}_{3}(\mathrm{Bim})_{12}$ reached to $100 \mathrm{mg}$, which was two times more than the former one. When $150 \mathrm{mg}$ $\mathrm{TbLa}_{3}(\mathrm{Bim})_{12}$ was used, the fluorescent intensity was the strongest. The emission peaks at 489, 543, 588 and $620 \mathrm{~nm}$ can be assigned to ${ }^{5} \mathrm{D}_{4} \rightarrow{ }^{7} \mathrm{~F}_{6},{ }^{5} \mathrm{D}_{4} \rightarrow{ }^{7} \mathrm{~F}_{5},{ }^{5} \mathrm{D}_{4} \rightarrow{ }^{7} \mathrm{~F}_{4}$ and ${ }^{5} \mathrm{D}_{4} \rightarrow{ }^{7} \mathrm{~F}_{3}$ of $\mathrm{Tb}^{3+}$, and the peak at $543 \mathrm{~nm}$ exhibited the predominant emission intensity, which was just in the range of the green light wavelength band. The bright-field image, fluorescent image and the overlay image of the RBC-like particles were separately shown in Fig. 13B. The intense green fluorescence revealed that the $\mathrm{RBC}$-like $\mathrm{Fe}_{3} \mathrm{O}_{4} / \mathrm{TbLa}_{3}(\mathrm{Bim})_{12} /$ PLGA composite particles had excellent fluorescent properties, which was in accord with the predominant emission peak.

After the particles were added to the A549 cell culture medium for $24 \mathrm{~h}$, the cell imaging was achieved by fluorescent microscope. A bright green light was visualized in the fluorescent image (Fig. 14b), corresponded to the maximum emission wavelength of $543 \mathrm{~nm}$, indicating that the $\mathrm{Fe}_{3} \mathrm{O}_{4} / \mathrm{TbLa}_{3}(\mathrm{Bim})_{12} /$ PLGA composite particles exhibited an excellent fluorescent property and could potentially function for drug labeling even after being incubated with cells for $24 \mathrm{~h}$ or more hours. Moreover, no fluorescence quenching appeared after 24 h. Remarkably, the particles mainly centralized on the cells (Fig. 14a and c), revealing the outstanding targeting ability towards cells. This might be because the RBC morphology was easily attached to the soft cells.

\subsection{The hydrophobicity-hydrophilicity of the $\mathrm{RBC}$-like $\mathrm{Fe}_{3} \mathrm{O}_{4} /$ $\mathrm{TbLa}_{3}(\mathrm{Bim})_{12} /$ PLGA composite particles}

For most biological system, dispersion of particles in the aqueous phase is required. Many researchers found that cell adherence growth greatly depends on the increase in
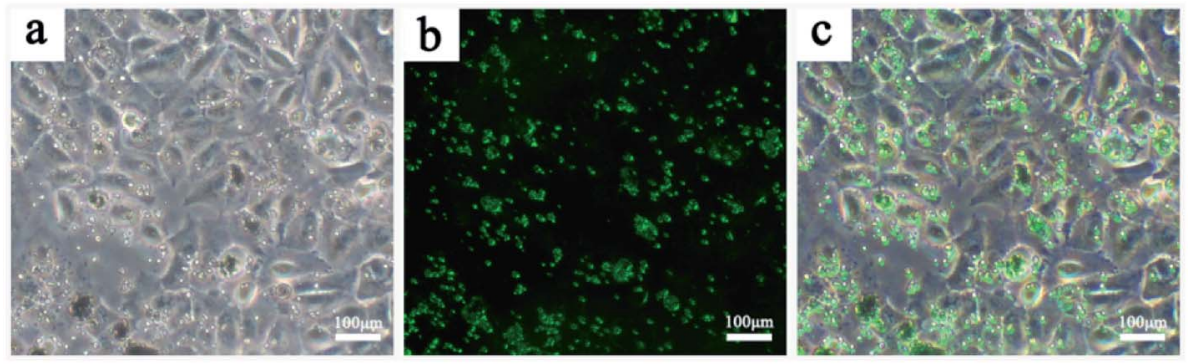

Fig. 14 Fluorescent microscope images of A549 cells incubated with the RBC-like $\mathrm{Fe}_{3} \mathrm{O}_{4} / \mathrm{TbLa}_{3}(\mathrm{Bim})_{12} / \mathrm{PLGA}$ composite particles. (a) Brightfield image, (b) fluorescent image (c) the overlay of the bright-field and fluorescent image. 


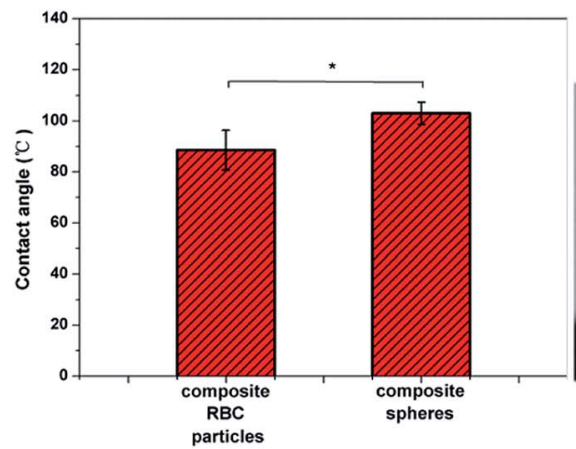

A
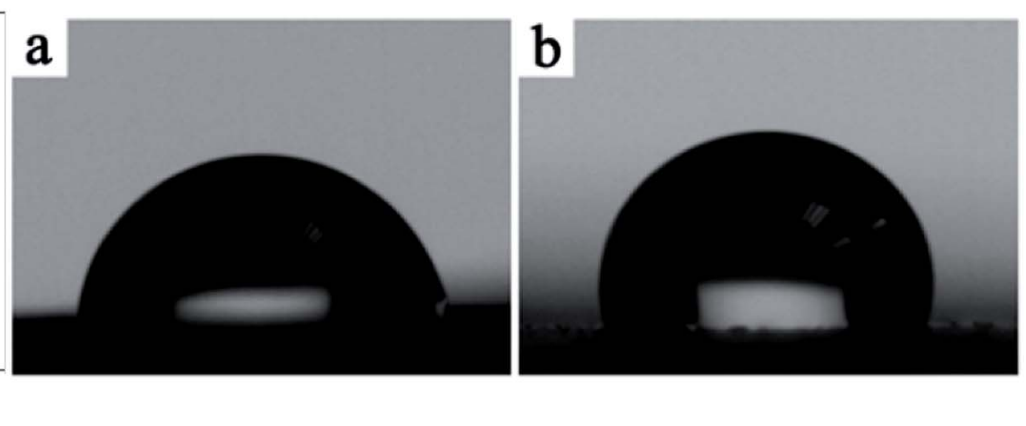

B

Fig. 15 (A) Contact angles of two different samples. "*" Indicates significant difference of $p<0.05$; (B) images of water droplets on different samples. (a) RBC-like $\mathrm{Fe}_{3} \mathrm{O}_{4} / \mathrm{TbLa}_{3}(\mathrm{Bim})_{12} / \mathrm{PLGA}$ composite particles, (b) $\mathrm{Fe}_{3} \mathrm{O}_{4} / \mathrm{TbLa}_{3}(\mathrm{Bim})_{12} / \mathrm{PLGA}$ composite spheres.

hydrophobicity-hydrophilicity. ${ }^{37}$ It was reported that moderate contact angle $\left(40-70^{\circ}\right)$ would be better to adsorb cell adhesive protein, which caused cell attachment. ${ }^{38}$ PLGA has been widely used in biomedical application. However, the hydrophobicity limited the further usage. Therefore, it was necessary to explore the hydrophobicity-hydrophilicity of biomaterials synthesized by PLGA. To examine the hydrophobicity-hydrophilicity of the RBC-like PLGA particles, we measured the contact angles of the RBC-like $\mathrm{Fe}_{3} \mathrm{O}_{4} / \mathrm{TbLa}_{3}(\mathrm{Bim})_{12} / \mathrm{PLGA}$ composite particles (S6 in Table 1) and the $\mathrm{Fe}_{3} \mathrm{O}_{4} \mathrm{TbLa}_{3}(\mathrm{Bim})_{12} / \mathrm{PLGA}$ composite spheres. The composite spheres were electrosprayed with 10\% PLGA, and other dosages were consistent with sample (S6). As shown in Fig. 15, the contact angles of the RBC-like $\mathrm{Fe}_{3} \mathrm{O}_{4} / \mathrm{TbLa}_{3}(-$ Bim) ${ }_{12} /$ PLGA composite particles and the $\mathrm{Fe}_{3} \mathrm{O}_{4} / \mathrm{TbLa}_{3}(\mathrm{Bim})_{12} /$ PLGA composite spheres were $88.53^{\circ}$ and $103.92^{\circ}$ respectively. The RBC-like particles exhibited a smaller contact angle than the spheres, which increased the hydrophobicity of the particles. The results suggested that the RBC-like $\mathrm{Fe}_{3} \mathrm{O}_{4} / \mathrm{TbLa}_{3}(-$ Bim) $)_{12} /$ PLGA composite particles may exhibit better biocompatibility between materials and cells.

\subsection{The cytotoxicity of the RBC-like $\mathrm{Fe}_{3} \mathrm{O}_{4} / \mathrm{TbLa}_{3}(\mathrm{Bim})_{12} /$ PLGA composite particles}

The cytotoxicity of the RBC-like $\mathrm{Fe}_{3} \mathrm{O}_{4} / \mathrm{TbLa}_{3}(\mathrm{Bim})_{12} / \mathrm{PLGA}$ composite particles was determined by the CCK- 8 assay. The viability of untreated A549 cells was assumed to be $100 \%$. The results revealed that the cell viability of all experimental groups at different concentrations from 7.81 to $1000 \mu \mathrm{g} \mathrm{mL}{ }^{-1}$ was declined to some extent after incubation for $24 \mathrm{~h}$, as shown in Fig. 16. Nevertheless, cell viability was still more than $90 \%$ even at the high concentration of $1000 \mu \mathrm{g} \mathrm{mL}^{-1}$ of the RBC-like $\mathrm{Fe}_{3} \mathrm{O}_{4} /$ $\mathrm{TbLa}_{3}(\mathrm{Bim})_{12} / \mathrm{PLGA}$ composite particles. The CCK-8 assay results demonstrated that the $\mathrm{Fe}_{3} \mathrm{O}_{4} / \mathrm{TbLa}_{3}(\mathrm{Bim})_{12} / \mathrm{PLGA}$ composite particles had low cytotoxicity. Furthermore, with the increase of the concentration, the cell viability showed no significant change. The $\mathrm{Fe}_{3} \mathrm{O}_{4} / \mathrm{TbLa}_{3}(\mathrm{Bim})_{12} / \mathrm{PLGA}$ composite particles would have excellent biocompatibility in additional biomedical applications.

\subsection{Hemolytic activity of $\mathrm{RBC}$-like $\mathrm{Fe}_{3} \mathrm{O}_{4} / \mathrm{TbLa}_{3}(\mathrm{Bim})_{12} / \mathrm{PLGA}$ composite particles}

A hemolysis assay was used to determine the toxicity of RBC-like $\mathrm{Fe}_{3} \mathrm{O}_{4} / \mathrm{TbLa}_{3}(\mathrm{Bim})_{12} / \mathrm{PLGA}$ composite particles on RBCs. Hemolysis results for samples (at a range of 7.81 to 250 $\mu \mathrm{g} \mathrm{mL}{ }^{-1}$ ) were given in Fig. 17. All samples hemolytic rates were below $5 \%$, which was thought to be the risky ratio described in ISO/TR7405 standard. ${ }^{39}$ Photographs of precipitated RBCs were also given, there was no obvious hemoglobin released from damaged cells, demonstrating that there was excellent blood biocompatibility between materials and RBCs.

\subsection{Protein corona assay}

Due to large surface-to-volume ratio and surface properties, micro and nanoparticles will rapidly absorb biomolecules to form 'protein corona'. This protein corona, which provides particles with a 'biological identity', not only alters the properties of particles but also determines subsequent physiological responses..$^{40}$ Thus, it is necessary to study the non-specific

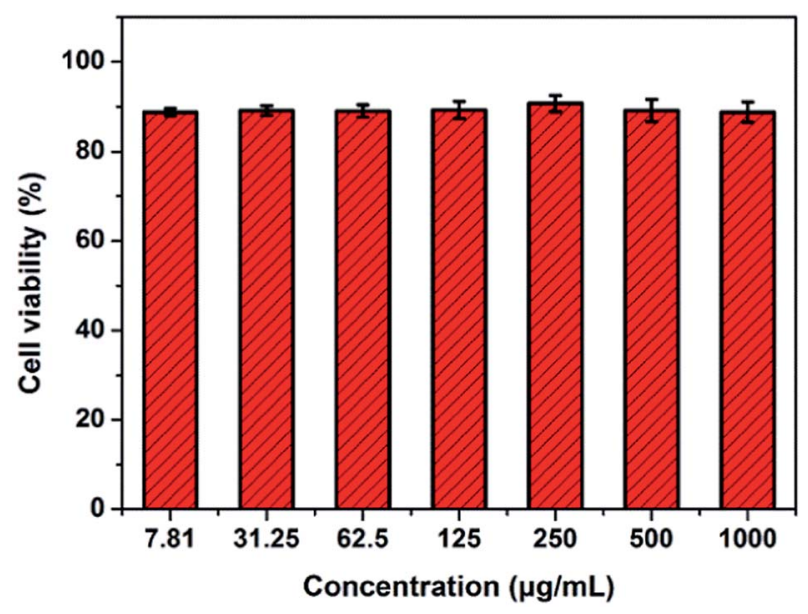

Fig. 16 In vitro A549 cells relative viabilities normalized to the untreated control after incubation for $24 \mathrm{~h}$ with different concentrations of the $\mathrm{RBC}$-like $\mathrm{Fe}_{3} \mathrm{O}_{4} / \mathrm{TbLa}_{3}(\mathrm{Bim})_{12} / \mathrm{PLGA}$ composite particles. 


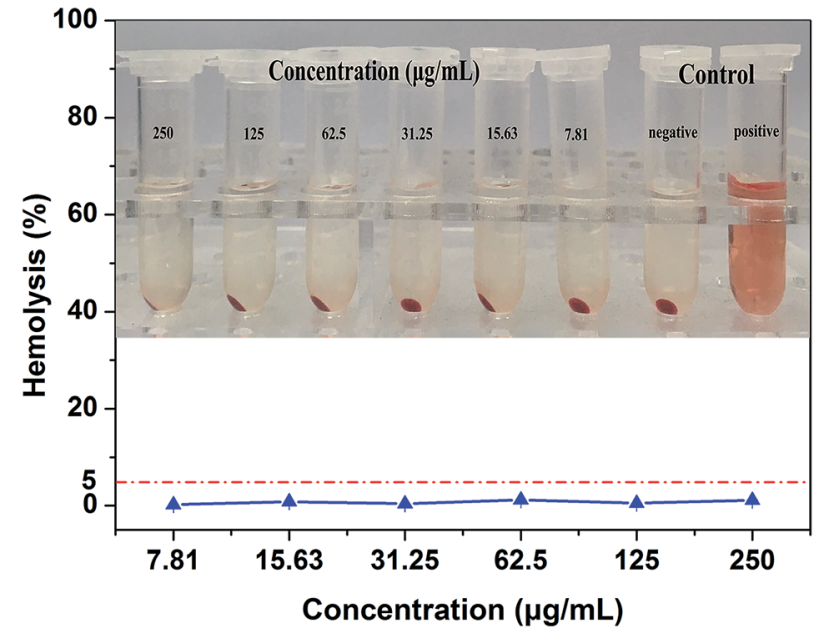

Fig. 17 Hemolysis rate and photographs of $\mathrm{RBC}$-like $\mathrm{Fe}_{3} \mathrm{O}_{4} / \mathrm{TbLa}_{3}(\mathrm{Bim})_{12} /$ PLGA composite particles at different concentration between 7.81 and $250 \mu \mathrm{g} \mathrm{mL}^{-1}$.

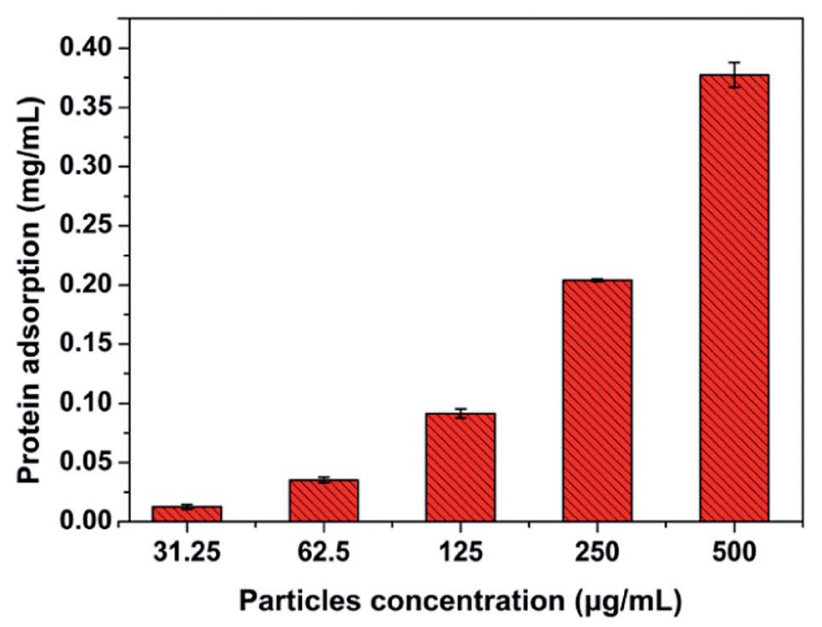

Fig. 18 Protein adsorption of RBC-like $\mathrm{Fe}_{3} \mathrm{O}_{4} / \mathrm{TbLa}_{3}(\mathrm{Bim})_{12} / \mathrm{PLGA}$ composite particles.

protein adsorption on particles. The protein corona was determined in RPMI-1640 culture medium with 10\% FBS by BCA Protein Assay Kit. The results of protein adsorption were shown in Fig. 18. The protein adsorption increased with the concentration of particles, which suggested that a proper particles concentration should be considered to utilize or minimize the influence of protein corona.

\section{Conclusions}

The RBC-like magnetic-fluorescent bifunctional $\mathrm{Fe}_{3} \mathrm{O}_{4}$ / $\mathrm{TbLa}_{3}(\mathrm{Bim})_{12} / \mathrm{PLGA}$ composite particles were successfully prepared by electrospraying. The generation of RBC-like structure was mainly related to the properties of the solutions, such as the choice of solvent, PLGA concentrations, and flow rate of the solutions. However, external control variable like collecting distance had smaller influence on the formation of the RBC-like structure, mainly affecting the particles size. In this study, the optimal parameters to obtain the RBClike particles were using THF as solvent, 2.5-5\% PLGA concentration, $15 \mathrm{~cm}$ collecting distance and $0.8 \mathrm{~mL} \mathrm{~h}^{-1}$ flow rate. Several results suggested that the $\mathrm{RBC}$-like $\mathrm{Fe}_{3} \mathrm{O}_{4} /$ $\mathrm{TbLa}_{3}(\mathrm{Bim})_{12} /$ PLGA composite particles have excellent, tunable magnetism and fluorescent properties. The RBC morphology could increase the hydrophilicity of the particles. Finally, the cells experiments showed that the RBC-like particles have low toxicity and excellent biocompatibility. The fluorescence of materials can be clearly observed while incubated with A549 cells, whereby the accurate drug tracking can be achieved. Additionally, under the influence of a magnetic field, the RBC-like particles showed excellent magnetic response. This RBC-like magnetic-fluorescent bifunctional $\mathrm{Fe}_{3} \mathrm{O}_{4} / \mathrm{TbLa}_{3}(\mathrm{Bim})_{12} /$ PLGA composite particles offer promising potential for application in the biomedical field, especially in DDS.

\section{Conflicts of interest}

There are no conflicts to declare.

\section{Acknowledgements}

This work was supported by funds from National Natural Science Foundation of China (NSFC) Research Grant (11472032, 31470901, 51401007, 31470915), and also supported by 111 Project (B13003), Foundation for the Author of National Excellent Doctoral Dissertation of PR China (201463), and International Joint Research Centre of Aerospace Biotechnology and Medical Engineering, Ministry of Science and Technology, China.

\section{References}

1 H. Yadav, P. Kumar, V. Sharma, G. Sharma, B. Raza and O. P. Katare, RSC Adv., 2016, 6, 53351-53357.

2 G. Minigo, A. Scholzen, C. K. Tang, J. C. Hanley, M. Kalkanidis, G. A. Pietersz, V. Apostolopoulos and M. Plebanski, Vaccine, 2007, 25, 1316-1327.

3 L. J. Lu, Y. Wang, M. H. Cao, M. W. Chen, B. L. Lin, X. H. Duan, F. Zhang, J. J. Mao, X. T. Shuai and J. Shen, RSC Adv., 2017, 7, 15041-15052.

4 D. Y. Tang, X. Zhao, T. Yang and C. Wang, RSC Adv., 2018, 8, 380-389.

5 Y. F. Ma, Y. Ji, M. L. You, S. R. Wang, Y. Q. Dong, G. R. Jin, M. Lin, Q. Wang, A. Li, X. H. Zhang and F. Xu, Acta Biomater., 2016, 42, 199-208.

6 S. F. Wang, C. T. Zhao, P. Liu, Z. Wang and J. S. Ding, RSC Adv., 2018, 8, 444-453.

7 Y. Hao, Y. X. Huang, Y. Q. He, J. R. Peng, L. J. Chen, X. Hu and Z. Y. Qian, RSC Adv., 2016, 6, 13698-13709.

8 D. M. Richards and R. G. Endres, Proc. Natl. Acad. Sci. U. S. A., 2016, 113, 6113-6118.

9 K. Vahidkhah and P. Bagchi, Soft Matter, 2015, 11, 20972109. 
10 J. Carolyn, V. S. Vladimir, B. Mark, R. M. Vladimir and D. D. Thomas, Curr. Pharm. Des., 2016, 22, 1259-1273.

11 Y. Geng, P. Dalhaimer, S. S. Cai, R. Tsai, M. Tewari, T. Minko and D. E. Discher, Nat. Nanotechnol., 2007, 2, 249-255.

12 B. Godin, C. Chiappini, S. Srinivasan, J. F. Alexander, K. Yokoi, M. Ferrari, P. Decuzzi and X. W. Liu, Adv. Funct. Mater., 2012, 22, 4225-4235.

13 P. Decuzzi and M. Ferrari, Biophys. J., 2008, 94, 3790-3797. 14 P. Decuzzi and M. Ferrari, Biomaterials, 2006, 27, 5307-5314.

15 J. P. Best, Y. Yan and F. Caruso, Adv. Healthcare Mater., 2012, 1, 35-47.

16 A. F. Galvao, T. Petta, N. Flamand, V. R. Bollela, C. L. Silva, L. R. Jarduli, K. C. R. Malmegrim, B. P. Simoes, L. A. B. Moraes and L. H. Faccioli, Anal. Bioanal. Chem., 2016, 408, 3613-3623.

17 S. Mitragotri and J. Lahann, Nat. Mater., 2009, 8, 15-23.

18 V. Kozlovskaya, J. F. Alexander, Y. Wang, T. Kuncewicz, X. W. Liu, B. Godin and E. Kharlampieva, ACS Nano, 2014, 8, 5725-5737.

19 T. J. Merkel, S. W. Jones, K. P. Herlihy, F. R. Kersey, A. R. Shields, M. Napier, J. C. Luft, H. L. Wu, W. C. Zamboni, A. Z. Wang, J. E. Bear and J. M. Desimone, Proc. Natl. Acad. Sci. U. S. A., 2011, 108, 586-591.

20 J. B. Fan, Y. Y. Song, H. F. Li, J. P. Jia, X. L. Guo and L. Jiang, J. Mater. Chem. B, 2014, 2, 3911-3914.

21 Y. H. Lee, F. Mei, M. Y. Bai, S. L. Zhao and D. R. Chen, J. Controlled Release, 2010, 145, 58-65.

22 W. P. Lv, K. J. Lee, S. Hwang, T. H. Park, F. B. Zhang and J. Lahan, Part. Part. Syst. Charact., 2013, 30, 936-939.

23 S. Sahoo, W. C. Lee, J. C. Goh and S. L. Toh, Biotechnol. Bioeng., 2010, 106, 690-698.

24 J. W. Xie, J. Jiang, P. Davoodi, M. P. Srinivasan and C. H. Wang, Chem. Eng. Sci., 2015, 125, 32-57.
25 K. Hayashi, K. Ono, H. Suzuki, M. Sawada, M. Moriya, W. Sakamoto and T. Yogo, Small, 2010, 6, 2384-2391.

26 C. H. Park, N. Chung and J. Lee, J. Colloid Interface Sci., 2011, 361, 423-428.

27 X. J. Ju, X. X. Wang, Z. Liu, R. Xie, W. Wang and L. Y. Chu, Particuology, 2017, 30, 151-157.

28 X. D. Lu, et al., Mater. Sci. Eng., C, 2018, 82, 190-196.

29 D. E. Hodges, K. M. McNally and A. J. Welch, J. Biomed. Opt., 2001, 6, 427-431.

30 L. Han, Q. l. Ma and X. T. Dong, RSC Adv., 2015, 5, 9567495681.

31 S. Fischer, C. Foerg, S. Ellenberger, H. P. Merkle and B. Gander, J. Controlled Release, 2006, 111, 135-144.

32 W. Wang, D. Xu, X. J. Wei and K. Z. Chen, Int. J. Nanomed., 2014, 9, 4879-4891.

33 P. Li, K. Li, X. F. Niu and Y. B. Fan, $R S C A d v ., 2016$, 6, 9903499043.

34 A. Yildirim, E. Ozgur and M. Bayindir, J. Mater. Chem. B, 2013, 1, 1909-1920.

35 J. Y. Lin, B. Ding, J. Y. Yu and Y. Hsieh, ACS Appl. Mater. Interfaces, 2010, 2, 521-528.

36 C. Wang, C. H. Hsu and J. H. Lin, Macromolecules, 2006, 39, 7662-7672.

37 J. H. Lee, G. Khang, J. W. Lee and H. B. Lee, J. Colloid Interface Sci., 1998, 205, 323-330.

38 Y. Wan, W. Chen, J. Yang, J. Bei and S. Wang, Biomaterials, 2003, 24, 2195-2203.

39 Y. Wang, N. Han, Q. Zhao, L. Bai, J. Li, T. Jiang and S. Wang, Eur. J. Pharm. Sci., 2015, 72, 12-20.

40 Q. Dai, N. Z. Bertleff, J. A. Braunger, M. Björnmalm, C. J. Cortez and F. Caruso, Adv. Healthcare Mater., 2018, 7, 1700575. 